
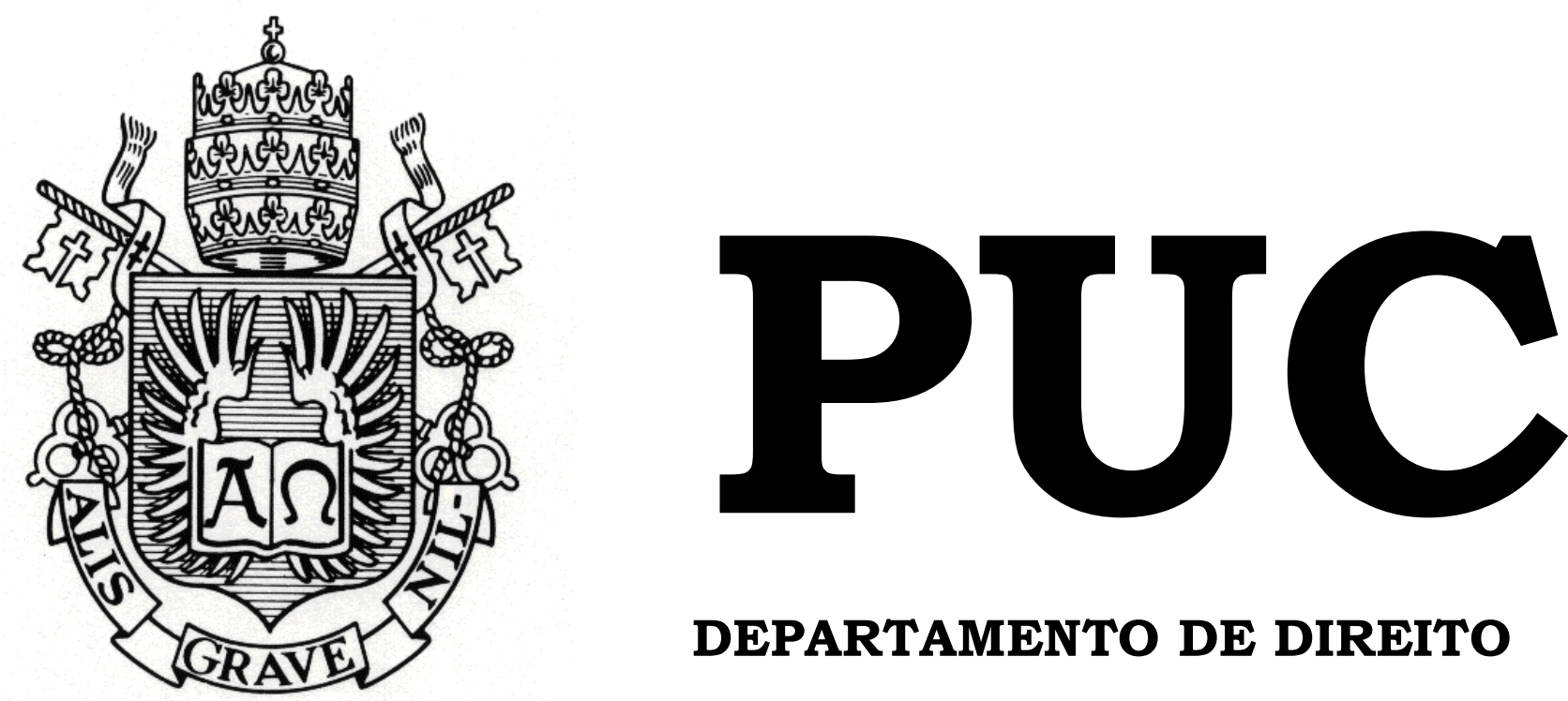

DEPARTAMENTO DE DIREITO

TAXA DE PERFORMANCE EM FUNDOS DE INVESTIMENTO REGULADOS PELA INSTRUÇÃO CVM No 409/04

por

Vitor Sampaio Tostes

ORIENTADOR: Marcelo Fernandez Trindade 2011.2

PONTIFÍCIA UNIVERSIDADE CATÓLICA DO RIO DE JANEIRO RUA MARQUÊS DE SÃO VICENTE, 225, GÁVEA - CEP 22453-900 RIO DE JANEIRO - BRASIL 


\title{
TAXA DE PERFORMANCE EM FUNDOS DE INVESTIMENTO REGULADOS PELA INSTRUÇÃO CVM N 409/04
}

\author{
por
}

\section{Vitor Sampaio Tostes}

Monografia apresentada ao Departamento de Direito da Pontificia Universidade Católica do Rio de Janeiro (PUC-Rio) como requisito parcial para obtenção do título de Bacharel em Direito.

Orientador: Marcelo

Fernandez Trindade 
À minha família. 


\section{Agradecimentos}

Agradeço aos meus pais, por tudo.

À Bel e Julia, que, sob (legítimos) protestos, foram pacientes e importantes para o resultado final do trabalho.

À equipe do BBM, pela fundamental compreensão no momento necessário.

Ao meu orientador, em nome da equipe do escritório Trindade Sociedade de Advogados, por toda a atenção despendida. 


\section{Resumo}

Nesse trabalho analisa-se, sob o ponto de vista jurídico, a taxa de performance cobrada por fundos de investimento regulados pela ICVM $\mathrm{n}$ 409/04. Após levantamento de aspectos gerais da indústria de fundos de investimento no Brasil, é realizada análise criteriosa sobre o mais recente posicionamento adotado pela CVM sobre a matéria (Processo Administrativo no 2010/3326). Partindo do caso concreto e utilizando uma análise indutiva, promove-se o debate de conceitos importantes que circundam o tema, tais como a natureza jurídica condominial sui generis dos fundos e a não aplicabilidade do CDC aos cotistas. Conclui-se que o cálculo individual da taxa de performance em relação a cada aquisição de cotas por cada cotista não infringe as diretrizes gerais editadas pela CVM ou pela legislação civil-consumerista, e representa uma solução original (que segue conceitos presentes no mundo off-shore) adotada pela maioria do mercado para lidar com as ineficiências intrínsecas à taxa de performance.

Palavras-chave: Taxa de Performance, Fundo de Investimento, Natureza Jurídica, Cálculo Individual. 


\section{Sumário}

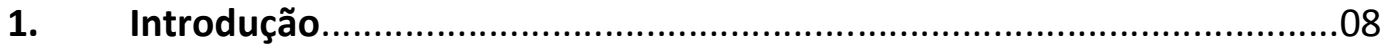

1.1. Importância dos fundos de investimento para o mercado financeiro...........11

1.2. Vantagens dos fundos de investimento (na ótica dos investidores)..............13

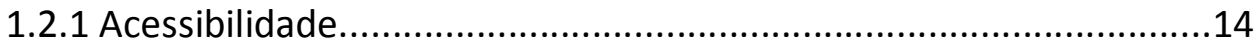

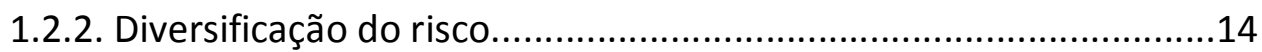

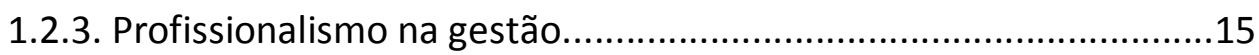

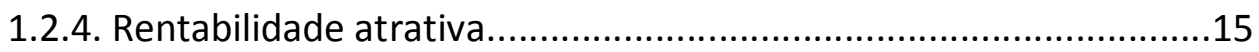

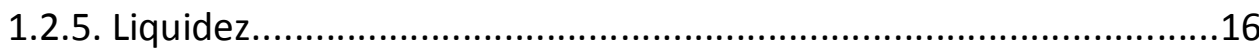

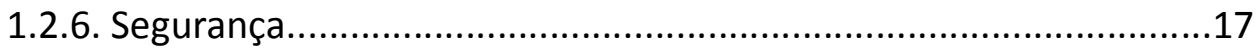

1.3. Panorama da indústria brasileira de fundos.................................................17

1.4. O papel da Regulação e da Autorregulação..................................................19

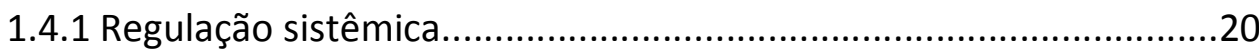

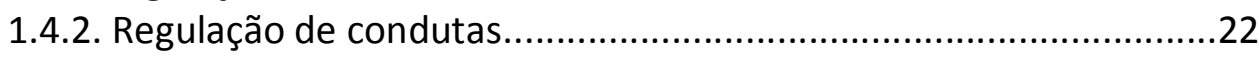

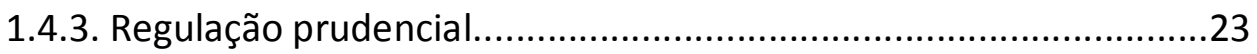

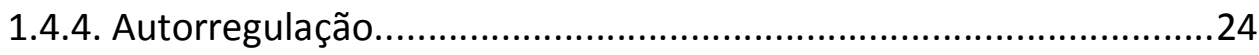

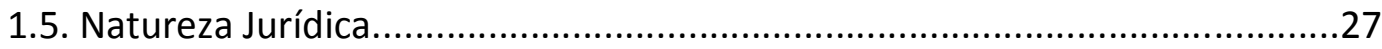

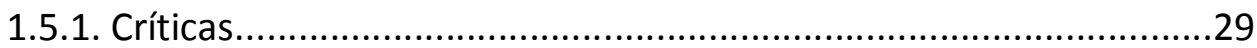

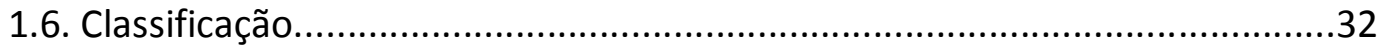

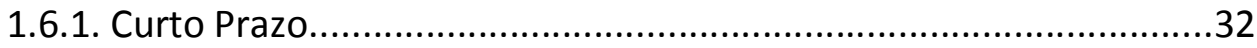

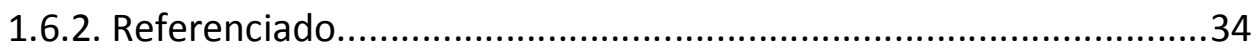

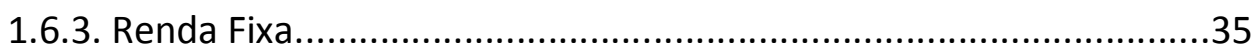

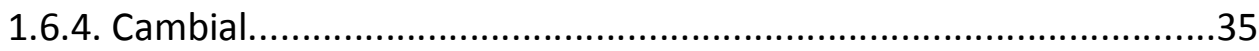

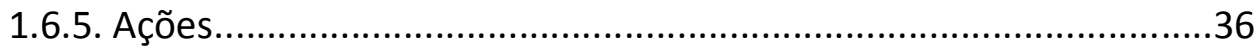

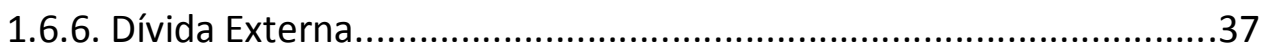

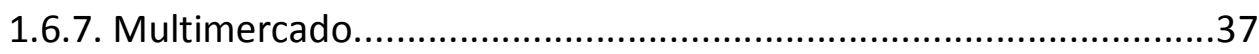

1.7. Principais prestadores de serviço....................................................................39

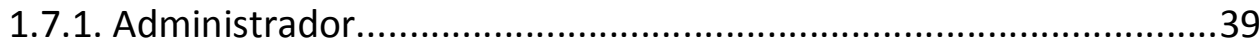

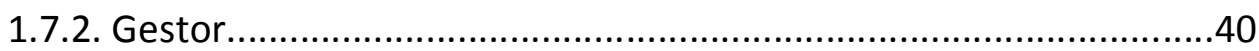

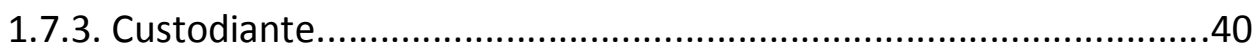

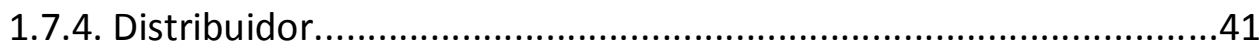

1.7.5. Divisão de Responsabilidades..................................................42

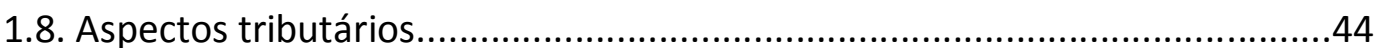

\section{Desenvolvimento}

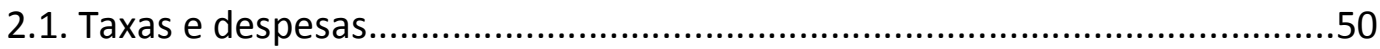

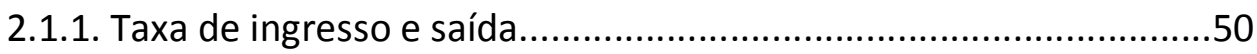

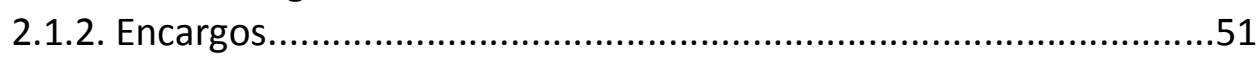

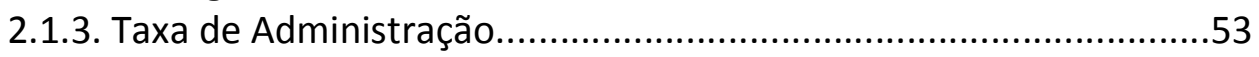


2.2. Taxa de performance - Processo Administrativo no 2010/3326.

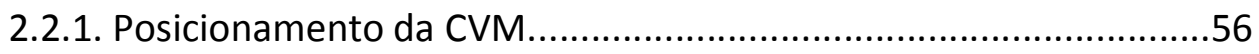

2.2.2. Argumentos a favor do cálculo individual....................................58

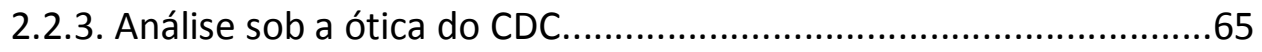

2.2.4. Não aplicabilidade do CDC aos cotistas........................................70

2.2.5. Soluções encontradas no mercado internacional..........................75

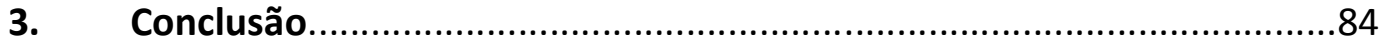

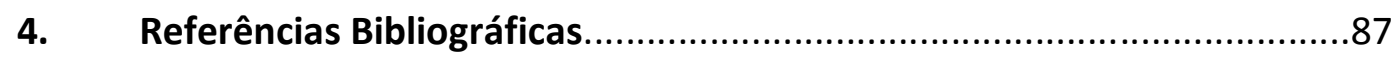




\section{Lista de Abreviações}

ADI: Ação Direta de Inconstitucionalidade

ANBID: Associação Nacional dos Bancos de Investimento

ANBIMA: Associação Brasileira das Entidades dos Mercados Financeiro e de Capitais

BACEN: Banco Central do Brasil

BDR: Brazilian Depositary Receipts

BM\&FBOVESPA: Bolsa de Valores, Mercadorias e Futuros

CDB: Certificado de Depósito Bancário

CDC: Código de Defesa do Consumidor, Lei n 8.078/1990

CDI: Certificado de Depósito Interbancário

CMN: Conselho Monetário Nacional

CONSIF:

CVM: Comissão de Valores Mobiliários

DTVM: Distribuidora de Títulos e Valores Mobiliários

FEBRABAN: Federação Brasileira de Bancos

FGC: Fundo Garantidor de Créditos

ICVM: Instrução CVM

IOF: Imposto sobre Operações de Crédito, Câmbio e Seguro, ou relativas a Títulos ou Valores Mobiliários

IR: Imposto de Renda

IN RFB: Instrução Normativa Receita Federal do Brasil

SDM: Superintendência de Desenvolvimento de Mercado

STF: Supremo Tribunal Federal

STJ: Superior Tribunal de Justiça 


\section{Introdução}

Este trabalho tem como objetivo aprofundar o estudo sobre o enquadramento jurídico da taxa de performance cobrada por fundos de investimento, partindo da análise de decisão proferida pela CVM, no primeiro semestre de 2011, no Processo Administrativo no 2010/3326.

A referida manifestação da autarquia, ao que tudo indica, será o leading case da matéria, sendo que a importância do tema se justifica pelos possíveis reflexos que a fixação de uma determinada interpretação pode gerar, extrapolando, inclusive, os limites do Direito e influenciando diversos setores da economia.

As particularidades envolvendo a taxa de performance (isto é, a obrigatoriedade de que ela seja cobrada da coletividade de cotistas, não obstante inexistir previsão regulatória sobre a forma pela qual deva ser calculada) faz com que esse encargo seja, também, o ponto de partida ideal para discutirmos temas correlatos cujos conceitos, por si só, mereceriam monografias independentes, tais como a natureza jurídica tanto dos fundos quanto da própria caracterização da figura do cotista de um fundo de investimento.

Tendo em vista as diversas modalidades ${ }^{1}$ de fundos de investimento regulados pela CVM, é válido esclarecer que o estudo restringirá o universo de análise especialmente àqueles regidos pela Instrução CVM no 409 de 2004 e alterações posteriores.

Por envolver uma espécie singular (taxa de performance) de um gênero que é bastante específico (fundo de investimento), procuramos expor os temas de forma clara e didática. Nossa intenção é demonstrar que, embora seja um nicho pouco explorado pelo público em geral, as questões relativas aos fundos

\footnotetext{
Como por exemplo: Fundos de Investimento em Participações, Fundos de Investimento Imobiliário, Fundos de Índice, com Cotas Negociáveis em Bolsa de Valores ou Mercado de Balcão Organizado, Fundos de Investimento em Direitos Creditórios, Fundos Mútuos de Privatização - FGTS, Fundos de Investimento em Empresas Emergentes, Fundos de Financiamento da Indústria Cinematográfica Nacional, etc.
} 
de investimento encontram suas respostas em fundamentos clássicos dos ramos tradicionais do Direito, como, por exemplo, Direito Civil e Empresarial.

A abordagem do tema baseia-se numa análise indutiva, partindo de um caso concreto, encarado como referência, que servirá de objeto de partida para outros questionamentos, possibilitando a comunicação entre diversas áreas do conhecimento jurídico. A metodologia é complementada, ainda, pela utilização do direito comparado, aqui entendido como método de pesquisa, ou seja, capaz de identificar semelhanças e diferenças do caso brasileiro com outros sistemas ao redor do mundo.

O instrumento de coleta de dados, por seu turno, foi pensado para abranger a jurisprudência administrativa, bem como artigos publicados em revistas especializadas e os mais variados livros (tanto de autores brasileiros como estrangeiros), propiciando uma análise mais abrangente, recorrendo sempre ao diálogo direto com a legislação/regulamentação aplicável.

O trabalho está estruturado em três partes principais:

Na primeira delas (introdução), o principal objetivo será ambientar o leitor, trazendo, na medida do possível, informações detidas pelos profissionais que militam na área. Demonstrar-se-á a importância dos fundos de investimento em dois níveis: inicialmente, para o desenvolvimento do mercado financeiro (sentido amplo), e depois destacando as vantagens que o veículo pode agregar ao cotista individualmente (sentido restrito).

Mapearemos a indústria de fundos atual no Brasil nas suas principais ramificações, desde os bancos de varejo até os serviços mais especializados dos Family Offices, passando pelo Private Banking e Asset Management. Em seguida, nos aprofundaremos no universo do Direito, sem deixar de fazer a devida relação dos conteúdos acadêmicos com a realidade econômica do assunto. Neste sentido, a análise da natureza jurídica condominial dos fundos de investimento é essencial para que os demais conceitos da monografia sejam compreendidos.

Como veremos adiante, a natureza jurídica dos fundos de investimento é pivô de inúmeros debates, na maioria dos casos suscitados por críticos à definição dada pela CVM que confere caráter condominial aos veículos. Defenderemos a noção de que o fundo é um condomínio sui generis (ou seja, 
com características especiais), sem chegar ao extremo de determinados autores que - através de festejados estudos - enxergam natureza associativa nos fundos, ou seja, um viés societário.

Superado esse tópico, finalizaremos a introdução esclarecendo (i) as diferentes classificações que os fundos de investimento regulados pela ICVM no 409/04 podem receber - fazendo o devido paralelo com a classificação conferida pela ANBIMA -, (ii) como se dá a atuação dos principais prestadores de serviço dos fundos e a divisão de responsabilidades entre eles - perante à CVM e aos cotistas, e (iii) questões tributárias enfrentadas pelos cotistas de fundos de investimento.

No desenvolvimento, detalharemos os mais relevantes custos que podem estar presentes nos fundos de investimento (ex: taxa de ingresso, saída, administração, etc.), campo no qual se insere a taxa de performance.

Com relação especificamente a essa última, será aberto um tópico próprio para tratar dos conceitos debatidos no Processo Administrativo no $2010 / 3326$.

Através de uma análise crítico-construtiva (e não mediante simples exposição dos argumentos invocados no supracitado Processo Administrativo), buscar-se-á demonstrar que os artigos 61 (§3으) e 62 da ICVM no 409/04 enumeram apenas diretrizes gerais para a disciplina da taxa de performance, passíveis de serem postas em prática de mais de uma forma, sem que as regras impostas pela regulação sejam contrariadas.

No mesmo item, visualizaremos a questão sob a ótica da legislação consumerista, para posteriormente concluir que os postulados do CDC foram observados no caso concreto e não representam óbice para o cálculo individual da taxa de performance, ainda que, no nosso entendimento, esse diploma legal não deve ser aplicado a cotistas de fundos de investimento.

Ainda no desenvolvimento, será a vez de analisar como outras jurisdições encaram as questões operacionais relativas à taxa de performance. Em virtude das suas próprias características intrínsecas (pagamento, no mínimo, semestral), é possível que ocorram ineficiências nos fundos que admitem aplicações e resgates em bases diárias. O objetivo da criação desse tópico, portanto, é 
reservar um espaço destinado a divulgação das soluções encontradas no mundo off-shore.

Por fim, a conclusão servirá para (i) retomar as principais discussões travas durante o trabalho, e (ii) convocar a doutrina brasileira a aprimorar os estudos referentes a fundos de investimento

\subsection{Importância dos fundos de investimento para o mercado financeiro}

O desenvolvimento da economia dos países passa, necessariamente, pelo aperfeiçoamento dos mecanismos de financiamento (especialmente de longo prazo) da produção e do consumo disponíveis no mercado.

A partir do momento em que se observa a presença simultânea de entes superavitários (cuja capacidade de poupar excede o montante destinado aos investimentos) e deficitários (aqueles, por sua vez, cujo apetite para investir exige uma quantidade maior de recursos do que os disponíveis através da poupança), faz-se necessária a criação de meios adequados para permitir a transferência de recursos entre ambos, com objetivos precípuos de otimizar a circulação de riquezas, reduzir custos e minorar riscos.

No passado, a função de intermediação de recursos era realizada primordialmente pela atividade bancária, mediante concessão de crédito (que consiste, em resumo, na captação de riquezas junto ao público para posterior repasse aos agentes deficitários, sendo que a remuneração da instituição financeira ${ }^{2}$ decorre da diferença da taxa de juros cobrada nas diferentes pontas da operação: spread).

Com o recente desenvolvimento do sistema financeiro no Brasil, verificou-se, também, a consolidação de mercados especializados (com diferentes condições de equilíbrio), tais como os mercados cambial, monetário e de capitais. Neste último, é possível identificar de forma mais clara o mesmo propósito do tradicional mercado de crédito, qual seja, a alocação eficiente de

O conceito de "instituição financeira" - bastante criticado pela doutrina em virtude da imprecisão e baixo rigor técnico - é tratado pelo nosso ordenamento jurídico tanto na Lei no 4.595/1964 (art. 17) quanto na Lei no 7.492/1986 (art. 1ㅇ). 
recursos entre os setores da economia, desta vez direcionando-os diretamente para a instituição emissora de valores mobiliários sem a necessidade da intermediação específica da instituição financeira. Nas palavras de OTAVIO YAZBEK:

"Por outro lado, no mercado de capitais (o 'mercado de valores mobiliários') a relação de financiamento se estabelece diretamente entre o prestador de recursos e o seu beneficiário, a partir da emissão, por este último, de obrigações primárias ou diretas (...), como ações, debêntures ou commercial papers, adquiridas por aquele primeiro. Também para este tipo de mercado são criadas estruturas de intermediação, tanto para as movimentações financeiras quanto para permitir a aproximação eficiente entre os agentes interessados. Neste caso, porém, os intermediários são meros intervenientes (e não mais contrapartes), prestando serviços de aproximação, de representação ou de liquidação de operações para seus clientes, as partes reais." ${ }^{3}$

Ainda que haja a possibilidade - constantemente incentivada - de acesso direto $^{4}$ aos mercados supramencionados ${ }^{5}$, os veículos de investimentos coletivos vêm assumindo papel fundamental no desenvolvimento da economia brasileira.

Esse papel de destaque passa justamente pela sua característica natural de mobilizar uma grande quantidade de recursos e direcioná-los, conjuntamente, de acordo com os objetivos previamente definidos, o que viabiliza grandes investimentos e aumenta a expectativa de retorno.

A título exemplificativo, de acordo com matéria veiculada no jornal Valor Econômico em 09 de setembro de 2011, apenas no mês de agosto foram criados 20 (vinte) Clubes de Investimento, elevando o número total para 2.926 (dois mil novecentos e vinte e seis), o que representa um patrimônio líquido total de $R \$$ 9,41 bilhões.

YAZBEK, Otavio. Regulação do Mercado Financeiro e de Capitais. Rio de Janeiro: Elsevier, 2007. p. 132.

Para atuar nos mercados regulados pela BM\&FBOVESPA, no entanto, é preciso cadastrar-se em uma Corretora de Títulos e Valores Mobiliários, ainda que ferramentas como o Home Broker e Direct Market Access permitam o envio/recebimento de ordens em tempo real pelo investidor.

5 A BM\&FBOVESPA escalou o Pelé como garoto propaganda para popularizar a dinâmica do investimento em ações. Atualmente, o número de investidores pessoa física registrados gira em torno de 600 mil, e a meta da companhia é elevar o número para cinco milhões no prazo de cinco anos. 
Com relação à caracterização legal dos títulos e contratos de investimento coletivo no ordenamento jurídico, a Lei no 6.385/76 (que dispõe sobre o mercado de valores mobiliários e cria a CVM) os define como valores mobiliários, nos termos do inciso IX do artigo 2울

“Art. 2ํ São valores mobiliários sujeitos ao regime desta Lei:

(...)

IX - quando ofertados publicamente, quaisquer outros títulos ou contratos de investimento coletivo, que gerem direito de participação, de parceria ou de remuneração, inclusive resultante de prestação de serviços, cujos rendimentos advêm do esforço do empreendedor ou de terceiros."

Dentre os diversos instrumentos de investimento coletivo, destacam-se os fundos de investimento como "um dos mais notáveis e democráticos instrumentos de alocação da poupança dos investidores, muitas vezes não afeitos à complexa dinâmica do mercado financeiro", conforme ressaltado por NELSON EIZIRIK ${ }^{6}$.

De acordo com dados ${ }^{7}$ divulgados pela ANBIMA, a indústria de fundos de investimento apresenta recorde de captação líquida no mês de setembro de 2011 (R\$ 7.9 bilhões), não obstante a apreensão que toma conta do mercado no que diz respeito aos temores de uma possível nova recessão da economia mundial.

É neste mesmo cenário de tensão que o valor dos ativos dos fundos registrados na ANBIMA atingiu a marca de $R \$ 1.8$ trilhões, tendo quase que duplicado se comparado aos valores existentes em 2007 (período de euforia dos mercados e anterior à histórica crise de 2008, cujas dimensões chegaram a ser comparadas com o crash da Bolsa de Nova lorque em 1929).

\subsection{Vantagens dos fundos de investimento (na ótica dos investidores)}

6 EIZIRIK, Nelson Laks et. al.. Mercado de Capitais - regime Jurídico. Rio de Janeiro: Renovar, 2008. p. 77.

Disponível em <http://www.anbima.com.br/mostra.aspx/?id=4603> - Boletim ANBIMA de Fundos de Investimento no 65. 
As razões pelas quais os fundos de investimento atraem cada vez mais a atenção do público podem ser sistematizadas da seguinte forma:

\section{- 1.2.1. Acessibilidade}

Uma das maiores barreiras à inserção dos investidores (principalmente pessoas físicas) no mercado financeiro é o custo de entrada, fazendo com que os recursos muitas vezes sejam destinados a aplicações não tão atraentes sob o ponto de vista da rentabilidade, entretanto mais acessíveis, como a poupança, por exemplo.

Enquanto os instrumentos de captação usualmente ofertados por instituições financeiras que apresentam taxas de rentabilidade atraentes exigem um elevado aporte de recursos, existem fundos de investimento abertos à captação com investimentos mínimos iniciais adequados à condição financeira de praticamente todos os potenciais investidores ${ }^{8}$.

Adicionalmente, a simplicidade na movimentação dos recursos é mais um dos atrativos dos fundos de investimento, sendo que, conforme o caso $^{9}$, ela pode ser realizada pelo telefone, internet, ou ainda através do caixa eletrônico, gerando maior comodidade ao cotista.

\section{- 1.2.2. Diversificação do risco}

A carteira dos fundos de investimento, nos limites do disposto nos respectivos Regulamentos (e, se for o caso, Prospecto), pode ser composta dos mais diversos tipos de ativos, de forma que os recursos dos cotistas não fiquem expostos exclusivamente a um único fator de risco. Em resumo, a diversificação é aconselhável para reduzir as possibilidades de perdas decorrentes do mau desempenho de um segmento específico da economia.

8 Para mais informações, acesse o Portal do Investidor. Disponível em $<w w w$.portaldoinvestidor.gov.br>.

Dependendo das características de cada fundo - descritas no Regulamento/Prospecto e das condições oferecidas pela instituição responsável pela administração do fundo. 
Um exemplo que ilustra bem a questão é uma rápida comparação do investimento em Fundos de Investimento Referenciados (nos termos do artigo 94 e seguintes da ICVM no 409) ou em Certificado de Depósito Bancário (CDB).

Ainda que num primeiro momento as aplicações possam passar a impressão de serem similares (tendo em vista que a remuneração de ambas acompanha - ou pretende acompanhar - a variação do Certificado de Depósito Interbancário - $\mathrm{CDI}$ ), o investidor está potencialmente sujeito a dois fatores de risco diametralmente opostos: risco de crédito da instituição financeira emissora do título, no caso dos CDBs; e risco de crédito de crédito do governo brasileiro, no caso dos Fundos Referenciados (já que estes aplicam no mínimo $80 \%$ de seu patrimônio líquido em títulos de emissão do Tesouro Nacional ou do Banco Central do Brasil).

\section{- 1.2.3. Profissionalismo na gestão}

Os recursos utilizados pelo investidor na aquisição das cotas passam a integrar patrimônio líquido do fundo de investimento. A partir deste momento, eles ficam à disposição da entidade responsável pela gestão do fundo que, nos termos do §2 do Artigo 56 da ICVM 409, é devidamente autorizada pela CVM a atuar como administradora de carteiras e detém poderes para negociar, em nome do fundo, títulos e valores mobiliários.

Nesse sentido, o cotista confia parte das suas economias a uma equipe especializada capaz de avaliar cenários econômicos e políticos nacionais e internacionais, monitorar a liquidez dos ativos, desenvolver modelos de controle de risco para montar, através de análises fundamentalistas e/ou quantitativas, um portfólio adequado àquele determinado fundo de investimento.

\section{- 1.2.4. Rentabilidade atrativa}

Via de regra, a rentabilidade proporcionada pelos fundos de investimento excede a dos instrumentos convencionais disponíveis no mercado, mesmo com a 
eventual incidência de taxas (como taxa de administração, performance, entrada, saída, corretagem, etc.).

Embora o corte na taxa de juros pelo Copom ou a alta volatilidade do mercado acionário, por exemplo, façam com que produtos mais conservadores ganhem maior representatividade junto ao público, deve-se observar que, historicamente, a rentabilidade dos veículos coletivos tende a se mostrar mais favorável.

Além disso, é válido destacar que o percentual de rentabilidade é o mesmo para pequenas ou relevantes aplicações em um fundo, tendo em vista que ambas compõem o mesmo patrimônio sob gestão.

Ressalte-se, no entanto, que tanto a CVM quanto a ANBIMA, na missão institucional de proteção ao investidor de varejo que tem pouca familiaridade com o mercado financeiro, obrigam - de maneira acertada - as instituições responsáveis pela elaboração de materiais de venda relativos a fundos de investimento a divulgarem que a rentabilidade passada não é garantia de rentabilidade futura ${ }^{10}$.

\section{- 1.2.5. Liquidez}

Observadas as eventuais restrições específicas de cada fundo, os resgates de cotas podem ser solicitados a qualquer momento em fundos abertos. As regras de conversão das cotas e pagamento dos resgates obrigatoriamente estarão contidas na documentação cadastral dos fundos (Regulamento e Prospecto), de forma que o investidor sabe, de antemão, o prazo que deverá aguardar para ter os recursos em mãos em caso de necessidade.

Enquanto a realização dos lucros de uma aplicação em títulos públicos através do Tesouro Direto ${ }^{11}$, por exemplo, pode levar anos (na hipótese do Diretrizes para Publicidade e Divulgação de Material Técnico para Fundos de Investimento da ANBIMA. 
investidor não se desfazer do título no mercado secundário de renda fixa, que ainda é incipiente ${ }^{12}$, ou não estar disposto a suportar o deságio gerado pela recompra efetuada semanalmente pelo Tesouro Nacional), o procedimento de resgate de cotas de um Fundo Referenciado que aplica na mesma classe/série de ativo será concluído, na maioria dos casos, em poucos dias.

\section{- 1.2.6. Segurança}

O arcabouço de normas editadas pela CVM (e, paralelamente, pela ANBIMA) expõe a indústria de fundos a uma intensa fiscalização, que passa pelo envio diário de dados aos órgãos reguladores, até supervisões in loco das instituições prestadoras de serviços contratadas pelo fundo.

As demonstrações financeiras dos fundos, por exemplo, são auditadas anualmente por auditor independente, e devem necessariamente ser submetidas ao crivo da Assembleia Geral de Cotistas.

Todas essas medidas transmitem segurança ao investidor, que tem a convicção de aplicar seus recursos em um dos mercados mais regulados do mundo.

\subsection{Panorama da indústria brasileira de fundos}

Conforme mencionado anteriormente, os fundos são veículos de investimento a partir dos quais diversos produtos (dos mais simples aos mais complexos) podem ser estruturados. Essa flexibilidade faz surgir uma grande variedade de segmentos, como por exemplo: fundos organizados por grandes 
bancos de varejo ${ }^{13}$, áreas de Asset Management, Private Banking e Family Offices.

Com relação aos bancos de varejo, a maioria dos veículos criados visam oferecer opções de diversificação de patrimônio a pequenos e médios investidores, que muitas das vezes já são correntistas da instituição administradora/gestora dos fundos. O maior trunfo desses fundos é a credibilidade que a marca dos principais bancos possui junto à população, fazendo com que eles sejam automaticamente - e de forma precipitada associados a um investimento de baixo risco.

Privilegiando investidores com maior poder aquisitivo e com conhecimento prévio do mercado financeiro, as gestoras independentes atuam no segmento de Asset Management e são responsáveis pela gestão de fundos mais sofisticados. Normalmente, por trás das gestoras independentes estão nomes reconhecidamente consagrados no mercado, com respeitáveis tracking records e vasta experiência no ramo de gestão de recursos de terceiros ${ }^{14}$.

Aqueles clientes exclusivos que buscam um completo assessoramento dos seus investimentos costumam recorrer ao Private Banking. Através desse serviço, equipes especializadas podem estruturar produtos sob medida, analisar de forma completa o risco do portfólio e auxiliar tanto em questões de planejamento sucessório quanto em reestruturações envolvendo sociedades nas quais o cliente detenha participação.

Os Family Offices, por sua vez, possuem propósitos semelhantes aos do Private Banking, entretanto se notabilizaram pela prestação de serviços altamente personalizados (cuja centralização leva a um natural abatimento dos custos totais) e que buscam a perpetuação do patrimônio de famílias bem sucedidas.

Em todos os casos supracitados, os fundos de investimento têm participação fundamental. Especificamente para os segmentos de Asset

13 Tais como Bradesco, Banco do Brasil, Itaú-Unibanco, etc.

14 A título exemplificativo, tanto a Gávea Investimentos quanto a Rio Bravo Investimentos possuem como principais sócios ex-presidentes do Banco Central do Brasil (Armínio Fraga e Gustavo Franco, respectivamente). 
Management, Private Banking e Family Offices, a possibilidade de estruturação de fundos de investimento exclusivos ${ }^{15}$ ou restritos ${ }^{16}$ é um grande diferencial, pois apresenta, dentre outras vantagens, (i) legislação tributária favorável, se o fundo for estruturado na forma de condomínio fechado (tendo em vista a não incidência do "come-cotas", que será explicado mais adiante); (ii) proteção à identidade do cotista, pois apenas a denominação social do fundo é divulgada no site da CVM; (iii) consolidação numa única cota da rentabilidade acumulada da carteira como um todo; e (iv) abertura para negociação de taxas de administração e/ou performance mais baixas, variando de acordo com o patrimônio líquido do fundo.

\subsection{O papel da Regulação e da Autorregulação}

O mercado financeiro brasileiro não foi afetado pela crise de 2008 das hipotecas subprime da forma avassaladora como outros centros ao redor do planeta.

Ainda hoje, a literatura econômica especializada questiona se tal fato se deu pela estrutura regulatória lato sensu vigente à época ou pela baixa complexidade dos ativos (principalmente os de crédito) e negociações ocorridas no mercado do Brasil, historicamente bastante exposto a títulos públicos.

Não obstante a discussão anteriormente citada, fato é que, de uma maneira geral, tanto os agentes responsáveis pela regulação do mercado de títulos e valores mobiliários quanto o próprio modelo adotado no Brasil saíram mais prestigiados (inclusive internacionalmente) desse período de turbulência.

Neste item serão abordados os diferentes campos de atuação dos referidos agentes na indústria pátria de fundos de investimento.

A atividade de regulação do sistema financeiro em espécie é doutrinariamente subdividida em quatro principais vertentes: (i) regulação

15 Fundos com apenas um cotista, de acordo com o artigo 111-A da ICVM no409/04.

16 Aqueles cujo público alvo corresponde a um "grupo determinado de investidores, que tenham entre si vínculo familiar, societário ou pertençam a um mesmo grupo econômico, ou que, por escrito, determinem esta condição", nos termos do Manual Técnico para Cadastro de Fundos na ANBIMA. 
sistêmica, (ii) regulação de condutas, (iii) regulação prudencial e (iv) autorregulação, sendo que esta última também pode se manifestar nos níveis "de condutas" e "prudencial".

\section{- 1.4.1. Regulação sistêmica}

A sociedade contemporânea é marcada pela ligação quase que umbilical entre os principais setores que a compõem, quais sejam, a economia, a política e o campo social. Observa-se, também, a crescente conexão/dependência entre os próprios agentes do mercado, potencializada cada vez mais pelo advento da globalização.

Ademais, levando-se em consideração a experiência empírica proporcionada pelos registros históricos, conclui-se que a economia mundial é cíclica, e as crises, por sua vez, recorrentes.

$\mathrm{Na}$ conjuntura atual, um choque pontual que atinja um agente do mercado (como, por exemplo, a decretação de intervenção ${ }^{17}$ de uma instituição financeira) pode, em razão do que foi descrito acima, se propagar com uma velocidade incrível.

Nesse sentido, a regulação sistêmica se encarrega de lançar um olhar panorâmico sob o sistema financeiro, sem deixar de lado, também, os reflexos que uma eventual crise pode desencadear nos setores tidos como "nãofinanceiros", o que pode se revelar altamente devastador.

"Tal regulação", de acordo com OTAVIO YAZBEK, "envolve a criação de 'redes de proteção' ou de mecanismos de 'blindagem' destinados a permitir a administração das crises ou a resolução de problemas, impedindo o seu alastramento" $^{18}$.

A respeito do assunto, GUSTAVO LOYOLA (ex-presidente do BACEN por duas vezes) afirma:

Nos termos da Lei no 6.024 de 13 de março de 1974.

YAZBEK, Otavio. Regulação do Mercado Financeiro e de Capitais. p. 190. 
"Um dos aspectos que distinguem a abordagem macroprudencial é que nesta o risco é considerado endógeno ao funcionamento do mercado financeiro, enquanto, na visão microprudencial, o risco é visto como exógeno à atuação de cada instituição. Ademais, sob o ponto macroprudencial, o fato de cada uma das firmas integrantes do sistema financeiro ser segura não significa necessariamente que o sistema como um todo seja seguro. Como consequência das diferenças conceituais entre as duas abordagens, sob a ótica macroprudencial, é perfeitamente admissível que o comportamento racional das firmas individualmente possa acarretar resultados agregados indesejáveis em termos de estabilidade financeira." ${ }^{19}$

Especificamente no âmbito dos fundos de investimento, é possível exemplificar o conceito do autor supracitado através da Resolução CMN no 3.334, de 22 de dezembro de 2005 .

O referido diploma estabelece, como regra, que os recursos próprios das instituições financeiras (ou de pessoas jurídicas diretamente ligadas), na qualidade de administradoras ou gestoras de carteira de fundos de investimento, não podem ser destinados à aquisição de cotas de fundos por elas administrados e/ou geridos que sejam ofertados ao público em geral, ressalvadas as hipóteses descritas na própria Resolução.

O principal objetivo do órgão deliberativo máximo do sistema monetário nacional ${ }^{20}$ é garantir que não haja "mistura" de recursos das instituições financeiras com patrimônio dos investidores comuns em determinados fundos de investimento.

Nesse caso, a preocupação é evitar o contágio de toda a sociedade em caso de situações de alta volatilidade e/ou insegurança do mercado financeiro, tendo em vista a clássica assimetria informacional detida pelos diferentes players (tema que será tratado de maneira mais aprofundada mais a frente).

LOYOLA, Gustavo. O futuro da regulação financeira. In: Garcia, Marcio; GIAMBIAGI, Fabio (Org.). Risco e Regulação: por que o Brasil enfrentou bem a crise e como ela afetou a economia mundial. Rio de Janeiro: Elsevier, 2010. p. 66. as diretrizes gerais das políticas monetária, cambial e creditícia; regular as condições de constituição, funcionamento e fiscalização das instituições financeiras e disciplinar os instrumentos de política monetária e cambial. O CMN é constituído pelo Ministro de Estado da Fazenda (Presidente), pelo Ministro de Estado do Planejamento e Orçamento e pelo Presidente do BACEN". 
Em outras palavras: as entidades responsáveis pela gestão/administração de fundos são capazes de detectar antes dos cotistas a ocorrência de cenários de stress $^{21}, \mathrm{e}$, consequentemente, resgatar seus recursos antes que a situação fique insustentável. Desta forma, o público em geral teria o ônus de arcar com todos os prejuízos daquele investimento.

\section{- 1.4.2. Regulação de condutas}

Principalmente através da utilização de comandos prescritivos, é possível que o regulador imponha determinados comportamentos à coletividade, visando a padronização ${ }^{22}$ das condutas que, através de uma relação diretamente proporcional, contribui para a segurança dos investidores.

Esta modalidade de regulação é aquela com maior expressão no modelo brasileiro, e que deve receber atenção especial nos próximos anos. No texto da ICVM no 409/04, podemos observar diversos dispositivos que expressam essa noção, conforme explicitado abaixo.

O § 3 ㅇ do artigo 2으 estabelece que somente podem compor a carteira do fundo ativos financeiros admitidos a negociação em bolsa de valores, de mercadorias e futuros, ou registrados em sistema de registro, de custódia ou de liquidação financeira devidamente autorizado pelo BACEN ou pela CVM, nas suas respectivas áreas de competência ${ }^{23}$.

O artigo 12, por sua vez, dispõe que a cota de fundo aberto não poderá ser objeto de cessão ou transferência, salvo por decisão judicial, execução de garantia ou sucessão universal.

YAZBEK, Otavio. Regulação do Mercado Financeiro e de Capitais. p. 189.: “(...) os detentores de quotas de fundos de investimento não teriam como avaliar as opções de investimento adotadas pelos administradores ou mesmo a atuação destes administradores". A padronização de condutas é feita, na medida do possível, a nível internacional. Respeitadas as peculiaridades do sistema adotado por cada país, a CVM promove um intercâmbio de informações com a IOSCO (International Organization of Securities Commissions) cada vez mais frequente após a assinatura do Memorando Multilateral de Entendimento. 
Já o artigo 29 enumera um conteúdo mínimo necessário que deve constar em quaisquer materiais de divulgação de cotas de fundo fechado.

Por fim, é válido destacar, por exemplo, o § 2 ㅇ do artigo 39, que obriga o administrador a publicar no site da CVM quaisquer alterações realizadas no Prospecto do fundo no prazo máximo de um dia útil.

Em resumo, todas as passagens destacadas acima (além de inúmeras outras que aparecem ao longo da ICVM n 409/04) buscam, através de normas imperativas, estabelecer regras negociais e/ou padrões de comportamento aos participantes da indústria de fundos de investimento, dando maior transparência e segurança jurídica ao mercado.

\section{- 1.4.3. Regulação prudencial}

Ao constatar que a economia como um todo está mais protegida, é possível que algumas instituições (com filosofias puramente especulativas e sem preocupação com objetivos de longo prazo) enxerguem neste cenário uma oportunidade para alavancar suas posições e assumir riscos excessivos, baseadas única a exclusivamente na crença de que um mercado regulado é sinônimo de porto seguro.

Nesse sentido, a regulação prudencial "se corporifica na criação de regras, padrões e procedimentos, ditos prudenciais, assim como no estabelecimento de estruturas de fiscalização e de supervisão das atividades desses intermediários, abrangendo a autorização para a prática de certos atos, o estabelecimento de limites, a obrigação de envio de informações e outras medida" ${ }^{24}$.

Observa-se, na prática, que a CVM implanta esse sistema quando estabelece, por exemplo, no $\S 1$ o do artigo 56 , que o administrador do fundo de investimento poderá contratar, em nome do fundo, apenas com terceiros devidamente habilitados e autorizados, os serviços de gestão da carteira do fundo, consultoria de investimentos, distribuição de cotas, dentre outros. 
Outras duas manifestações da regulação prudencial que merecem ser destacadas são:

- a criação da figura do investidor qualificado ${ }^{25}$ (cujas características serão estudadas com maior aprofundamento nos próximos capítulos) para restringir o acesso a produtos mais sofisticados a investidores que possuem prévio conhecimento do mercado financeiro; e

- conforme texto do Edital de Audiência Pública SDM no 06/11 para alteração da ICVM n .409/04, a obrigatoriedade do administrador "ter que adotar uma conduta que inclua políticas, práticas e controles internos que se façam necessários para garantir que a liquidez da carteira do fundo seja compatível com os prazos de resgate definidos nos regulamentos e também o cumprimento das obrigações do fundo, como por exemplo, os depósitos requeridos como margem" ${ }^{26}$.

- 1.4.4. Autorregulação ${ }^{27}$

O único caso brasileiro de autorregulação de base legal (isto é, cuja competência para o desempenho da atividade decorre da lei) é a experiência bursátil, nos termos do artigo 8으 (§ 1ํ) e 17 (parágrafo único) da Lei № 6.385/76:

“Art . 8o Compete à Comissão de Valores Mobiliários:

(...)

$\S 1$ ㅇ O disposto neste artigo não exclui a competência das bolsas de valores com relação aos seus membros e aos valores mobiliários nelas negociados.

(...)

Art. 17. As Bolsas de Valores, as Bolsas de Mercadorias e Futuros, as entidades do mercado de balcão organizado e as entidades de compensação e liquidação de operações com valores mobiliários terão autonomia administrativa, financeira e patrimonial, operando sob a supervisão da Comissão de Valores Mobiliários.

Vide artigo 109 da ICVM no 409/04.

O prazo para envio de críticas e sugestões ao texto proposto pela CVM no referido Edital encerrou-se, e as manifestações estão atualmente em período de análise. Uma das justificativas para o aprimoramento das regras de liquidez da carteira dos fundos é a tendência de aplicação em ativos com menos negociações no mercado em virtude do aumento da complexidade do mercado brasileiro.

Para uma análise aprofundada sobre o tema: TRINDADE, Marcelo Ferraz; SANTOS, Aline de Menezes. Regulação e Auto-Regulação no Brasil e a Crise Internacional. Disponível em <www.bmfbovespa.com.br/juridico/download/Artigo_MarceloTrindade.pdf $>$. 
$\S 1$ 10 Às Bolsas de Valores, às Bolsas de Mercadorias e Futuros, às entidades do mercado de balcão organizado e às entidades de compensação e liquidação de operações com valores mobiliários incumbe, como órgãos auxiliares da Comissão de Valores Mobiliários, fiscalizar os respectivos membros e as operações com valores mobiliários nelas realizadas." (grifo nosso)

No desenvolvimento da indústria de fundos de investimento, tanto no Brasil quanto no exterior, a autorregulação de base voluntária (aquela na qual os entes aderem espontaneamente às regras emanadas pelo autorregulador, ficando sujeitos a sanções contratuais características de direito privado), corporificada principalmente na ANBIMA, assume papel fundamental.

Os motivos pelos quais esse modelo vem sendo cada vez mais utilizado remontam à sua natureza privada, tradicionalmente mais ágil que o setor público.

Não restam dúvidas que as normas da ANBIMA possuem maior potencial de adesão e estão mais próximas da realidade dos participantes do que aquelas editadas pelo legislador ordinário, justamente pelo fato do seu corpo de integrantes ser composto exclusivamente por instituições atuantes no mercado.

Além disso, a possibilidade de ajustes/atualização nos Códigos de Regulação é extremamente dinâmica. Através da Deliberação no 49 (datada de 26 de agosto de 2011), por exemplo, a ANBIMA esclareceu conceitos das Diretrizes para Publicidade e Divulgação de Material Técnico para Fundos de Investimento ("Diretrizes") que estavam gerando dúvidas no mercado. Ressaltese, oportunamente, que as últimas alterações realizadas nas Diretrizes (através da Deliberação no 47) haviam entrado em vigor menos de dois meses antes, em 10 de julho de 2011.

Outra vantagem do sistema brasileiro é a possibilidade do regulador delegar tarefas ao ente autorregulador, como ocorreu no caso da ICVM no 497/11 (que dispõe sobre a atividade dos agentes autônomos de investimentos, e entrará em vigor em 10 de janeiro de 2012).

Com o intuito de dar maior eficiência ao procedimento de cadastro de novos profissionais, os artigos 18 e seguintes da referida Instrução preveem a possibilidade da CVM autorizar o credenciamento de agentes autônomos por 
entidades que comprovem ter estrutura adequada, com capacidade técnica e independência.

Naturalmente, a CVM exige o cumprimento de requisitos básicos (códigos de conduta, fiscalização permanente, exames de qualificação, programas de educação continuada, etc.), bem como o envio de relatórios periódicos para que tenha capacidade de analisar dados da indústria em geral.

Fato é que a conjugação de esforços entre CVM e ANBIMA contribui para aumentar a legitimidade das normas que atuam sob a indústria de fundos de investimento, além de reduzir as zonas cinzentas que possibilitam a arbitragem regulatória ${ }^{28}$.

O "Anuário 2011 da Indústria de Fundos de Investimento" 29 publicado pela ANBIMA em parceria com a Fundação Getúlio Vargas expõe de maneira concisa e objetiva as principais metas da autorregulação: busca da concorrência leal, padronização de procedimentos, maior transparência das informações, elevação dos padrões fiduciários e promoção das melhores práticas.

Não obstante as inúmeras vantagens proporcionadas pelo desenvolvimento da autorregulação, é preciso ressaltar que ela não é imune a críticas.

Todos os argumentos utilizados para, de alguma forma, contestar a eficácia desse sistema possuem como ponto de interseção a possibilidade concreta de conflito de interesses, que seria motivado pelo corporativismo dos agentes autorregulados.

Ainda que o risco anteriormente mencionado de fato exista, ele pode - e deve - ser mitigado. No caso da ANBIMA, por exemplo, verifica-se a manutenção de órgãos internos de controle corporificados em "Conselhos" (atualmente são

Arbitragem regulatória, segundo Marcelo Trindade e Aline Santos, é a "tendência dos agentes de mercado utilizarem os produtos menos onerosos do ponto de vista da regulação, com risco de prejuízo informacional, ou mesmo de aumento de custo para os investidores." (TRINDADE, Marcelo Ferraz; SANTOS, Aline de Menezes. Regulação e Auto-Regulação no Brasil e a Crise Internacional. p. 44.). É possível viabilizar claramente a preocupação da CVM com o assunto na edição das ICVM no 494/11 e 495/11. Essas duas Instruções revogaram a antiga ICVM no 40/84, que regulava de Clubes de Investimento de uma maneira menos aprofundada se comparada àquela destinada aos Fundos de Investimentos em Ações pela ICVM no 409/04. Disponível em <www.anbima.com.br/mostra.aspx/?id=1000001358>. 
sete Conselhos, com áreas de atuação específicas), que são eleitos indiretamente pelas próprias associações do mercado financeiro e de capitais.

\subsection{Natureza jurídica}

O artigo 2ำ da ICVM no 409/04 dispõe sobre a natureza jurídica dos fundos de investimento regidos por essa norma ao estabelecer que "o fundo de investimento é uma comunhão de recursos, constituída sob a forma de condomínio, destinado à aplicação em ativos financeiros".

Com a definição do caráter condominial dos fundos (e neste caso estamos falando de um condomínio voluntário e convencional), tem-se o ponto de partida para a sistematização das demais características desse tipo de veículo de investimento.

O aporte de recursos por parte dos investidores será alocado na seleção de ativos que, devidamente precificados, irão compor a carteira do fundo e corresponderão ao seu patrimônio líquido.

A contrapartida imediata do aporte de recursos é a emissão de cotas do fundo, que passam à titularidade do novo investidor. Estas correspondem a frações ideais (e não parcelas materiais, tendo em vista a fungibilidade do bem em questão: dinheiro) do patrimônio deste e conferem iguais direitos e obrigações aos cotistas como um todo ${ }^{30}$.

No entanto, a consequência mais relevante da natureza condominial é a ausência de personalidade jurídica dos fundos. Saliente-se, oportunamente, que os fundos de investimento são capazes de exercer direitos e contrair obrigações nas suas relações com o mundo exterior, desde que representados em toda e qualquer celebração de negócio jurídico pelo seu Administrador (ou terceiro legalmente contratado/constituído).

A redação da ICVM no 409/04, nesse ponto, vai diretamente ao encontro do conceito de "condomínio" elaborado por Caio Mário: "Dá-se condomínio, quando a mesma coisa pertence a mais de uma pessoa, cabendo a cada uma delas igual direito, idealmente, sobre o todo e cada uma de suas partes". (PEREIRA, Caio Mário da Silva. Instituições de direito civil - Volume IV. p. 151). 
O fato dos fundos possuírem inscrição no Cadastro Nacional de Pessoas Jurídicas do Ministério da Fazenda ("CNPJ/MF") funciona principalmente para identificar/individualizar cada um dos fundos, além de facilitar procedimentos com fins tributários, o que constantemente gera dúvidas no público leigo com relação ao assunto "personalidade jurídica em fundos de investimento".

Outro importante desdobramento do parágrafo anterior é aquele constante do artigo 13 da ICVM no 409/04:

"Art. 13. Os cotistas responderão por eventual patrimônio líquido negativo do fundo, sem prejuízo da responsabilidade do administrador e do gestor, se houver, em caso de inobservância da política de investimento ou dos limites de concentração previstos no regulamento e nesta Instrução." (grifo nosso)

Em tese, todos os fundos estão potencialmente expostos à ocorrência de patrimônio líquido negativo (basta considerar, por exemplo, a hipótese de default nos ativos da carteira, ou ainda a manutenção de $100 \%$ dos recursos em caixa - o que, no limite, corroeria o patrimônio com a incidência de taxas e encargos).

No entanto, vigora no mercado o entendimento equivocado, embora predominante, de que esse rótulo é dedicado apenas aos fundos que utilizam estratégias com derivativos ${ }^{31}$ para fins especulativos (e não apenas em operações de hedge).

A não ser na hipótese de responsabilização do administrador e/ou gestor por desvios nos respectivos mandatos (tema que será tratado de forma mais aprofundada adiante), a responsabilidade pelo aporte adicional/proporcional de recursos para cobrir o prejuízo do fundo é integralmente atribuída aos cotistas, 
corroborando entendimento da doutrina civilista capitaneada por CAIO MÁRIO DA SILVA PEREIRA (com base no artigo $1.317^{32}$ do Código Civil de 2002):

"Se acontecer que todos em conjunto contraiam dívida, sem discriminação da parte de cada um e sem que se estipule a solidariedade, entende-se que cada qual se obrigou proporcionalmente ao seu quinhão ou sorte, na coisa comum, e desta maneira, o débito será solvido e cobrado." ${ }^{33}$

Com relação aos conclaves realizados pelos condôminos, ainda nas palavras do eminente jurisconsulto, destaque para o fato das deliberações serem "tomadas não pelo número dos comunheiros, porém calculando-se a maioria pelo valor dos quinhões ou sortes. E para que obriguem a todos, serão as deliberações tomadas pela maioria absoluta, isto é, pelos votos que representem mais da metade do valor total" ${ }^{34}$. Tal entendimento aparece refletido no artigo 52 da ICVM no 409/04, que dispõe que "as deliberações da assembleia geral serão tomadas por maioria de votos, cabendo a cada cota 1 (um) voto".

\section{- 1.5.1. Críticas}

Recentemente, o número de críticos da teoria condominial adotada pela ICVM no 409/04 vem aumentando de maneira considerável. Dentre eles, destaca-se o advogado RICARDO DE SANTOS FREITAS, que publicou estudo ${ }^{35}$ completo sobre a matéria (que Ihe rendeu o título de Mestre em Direito Comercial pela Universidade de São Paulo) defendendo a natureza associativa dos fundos de investimento, aproximando-os das figuras do direito societário.

Primeiramente, a ausência de personalidade jurídica dos fundos é contestada:

\footnotetext{
“Art. 1.317. Quando a dívida houver sido contraída por todos os condôminos, sem se discriminar a parte de cada um na obrigação, nem se estipular solidariedade, entende-se que cada qual se obrigou proporcionalmente ao seu quinhão na coisa comum." PEREIRA, Caio Mário da Silva. Instituições de direito civil - Volume IV. 20ā ed. Rio de Janeiro, Editora Forense, 2009. p. 154. PEREIRA, Caio Mário da Silva. Instituições de direito civil - Volume IV. p. 155. FREITAS, Ricardo de Santos. Natureza Jurídica dos Fundos de Investimento. São Paulo: Quartier Latin, 2005. 287 p.
} 
"Afinal, se a personalidade jurídica manifesta-se através da aptidão para exercer direitos e obrigações por parte de um ente artificial, então não será a letra da lei dizendo não ter o ente personalidade jurídica que isoladamente terá valor. A correta apreciação deve passar pela análise do complexo feixe de relações obrigacionais alí existente, verificando exatamente quais capacidades jurídicas que a ele foram atribuídas pela regulamentação legal. Assim, entendemos ser possível propugnar a existência da personalidade jurídica em todas as organizações associativas que possuam, por disposição legal, algum grau de capacidade jurídica." ${ }^{36}$

Em seguida, é trazido à discussão o fato de ser inviável a aplicação subsidiária de conceitos gerais dos condomínios do direito civil em determinadas lacunas da regulação da CVM. Para ilustrar em termos práticos a questão, o autor faz uso do seguinte exemplo, dentre outros:

"Suponha-se que um administrador tenha, por erro, calculado a menor o valor do patrimônio líquido de um fundo no dia em que um investidor aportou recursos. Como consequência foi-lhe atribuída uma quantidade menor de cotas do que a devida. Qual remédio teria o investidor para recompor sua perda? 0 reconhecimento do fundo como condomínio poderia conduzir à aplicação da doutrina dos interditos possessórios, conforme inclusive prescreve o caput do art. 1.314 do Código Civil." ${ }^{37}$

Ainda são levantadas regras específicas atinentes aos condomínios que não se aplicam à disciplina dos fundos de investimento, como no caso da aparente incompatibilidade entre o artigo 1.314 do Código Civil ("cada condômino pode usar da coisa conforme a sua destinação, sobre ela exercer todos os direitos compatíveis com a divisão, defender a sua posse e aliar a respectiva parte ideal, ou gravá-la") e o artigo 12 da ICVM no 409/04 ("A cota de fundo aberto não pode ser objeto de cessão ou transferência, salvo por decisão judicial, execução de garantia ou sucessão universal").

Longe da pretensão de, em poucos parágrafos, esgotar o conteúdo da obra supracitada, ousamos discordar da corrente que prega a natureza societária dos fundos de investimento.

Conforme explicado por NELSON EIZIRIK, para que seja vislumbrado um viés societário nos fundos de investimento, Ihes falta um dos requisitos fáticos 
mais característicos das sociedades de pessoas no direito brasileiro, qual seja, a affectio societatis:

"Os fundos de investimento, ao contrário do que ocorre com as companhias de investimento, apresentam uma feição contratual e não societária, uma vez que não há entre os investidores relação interpessoal associativa - a affectio. Ao contrário, a relação dos investidores entre si é irrelevante para a constituição e funcionamento de um fundo, uma vez que ao aderirem ao fundo, estes vinculam-se ao administrador, que lhes presta serviços de administração e de gestão de recursos." ${ }^{38}$ (grifo nosso)

É importante pontuar que a delimitação do público alvo para um grupo de investidores pré-determinados (ex.: público alvo restrito, nos termos da classificação da ANBIMA) não se confunde com a affectio societatis, mas configura-se tão somente uma limitação ao ingresso de terceiros estranhos em produtos estruturados de maneira exclusiva para determinados clientes, que podem inclusive não ter nenhuma relação pessoal entre si (ex: fundos destinados a funcionários do administrador ou do gestor).

Precisamos concordar, no entanto, que não há a perfeita subsunção da disciplina civil dos condomínios à realidade dos fundos de investimento. Ou seja, as normas atinentes à disciplina dos condomínios não se aplicam integralmente aos fundos de investimento.

Nesse sentido, argumenta MILENE DONATO OLIVA:

“(...) a figura do condomínio ordinário prevista no Código Civil não se presta a explicar a complexa normativa incidente sobre os fundos de investimento. Nestes não cabe, com efeito, o direito potestativo à extinção do condomínio, nem a preferência por ocasião da alienação das cotas. Além disso, os quotistas não podem administrar diretamente os bens atribuídos ao fundo. O condomínio edilício menos ainda serve a esclarecer a disciplina aplicável aos fundos de investimento, vez que inexistem unidades autônomas, objeto de propriedade exclusiva, às quais se une, de maneira indissolúvel, a propriedade comum." ${ }^{39}$ (grifo nosso) 
Contudo, o posicionamento que nos parece mais razoável (e, naturalmente, ao qual nos filiamos) é aquele adotado por ARNOLD WALD, ainda na década de 90, defendendo a natureza jurídica de condomínio sui generis dos fundos imobiliários e alertando para a pouca relevância do nomen iuris:

“(...) quer se cogite de um condomínio especialíssimo ou sui generis, de uma sociedade de personalidade jurídica, na terminologia do Código de Processo Civil, ou de uma forma de trust já adaptada e consagrada pelo direito brasileiro, a designação e a semântica são secundários, pois o importante é a capacidade substantiva e adjetiva do fundo para adquirir e transmitir direitos, atuar em juízo, e praticar todos os atos da vida comercial, embora só possa exercer a sua atividade por intermédio do seu gestor." ${ }^{40}$ (grifo nosso)

\subsection{Classificação}

Conforme a composição das respectivas carteiras (e, consequentemente, os fatores de riscos aos quais estão expostos), os fundos de investimento podem ser classificados de sete maneiras diferentes, conforme disposto no artigo $92 \mathrm{da}$ ICVM no 409/04: Curto Prazo, Referenciado, Renda Fixa, Cambial, Ações, Dívida Externa, e Multimercado.

Sempre que possível, será feito o devido paralelo entre a classificação indicada pela CVM e aquela criada pela ANBIMA (atualizada pela última vez por meio da Deliberação no 44, de 24 de setembro de 2010), destacando os principais pontos de cada uma.

\section{- 1.6.1. Curto Prazo}

De acordo com o artigo 93 da ICVM no 409/04, "os fundos classificados como 'Curto Prazo' deverão aplicar seus recursos exclusivamente em títulos públicos federais ou privados pré-fixados ou indexados à taxa SELIC ou a outra taxa de juros, ou títulos indexados a índices de preços, com prazo máximo a decorrer de 375 (trezentos e 
setenta e cinco) dias, e prazo médio da carteira do fundo inferior a 60 (sessenta) dias, sendo permitida a utilização de derivativos somente para proteção da carteira e a realização de operações compromissadas lastreadas em títulos públicos federais".

Merece destaque o disposto no $\S 1$ 을 do referido artigo, que estabelece uma condição para a aquisição dos títulos privados mencionados no caput, qual seja, a obrigatoriedade de classificação do emissor dos ativos na categoria de baixo risco de crédito por agência de classificação de risco localizada do Brasil.

Buscando garantir uma proteção adicional ao cotista, a CVM se apoia nos serviços altamente técnicos de agências privadas de rating (atuando, neste caso, como gatekeepers), adotando postura típica de um regulador prudencial ${ }^{41}$.

Outra questão, envolvendo fundos de "Curto Prazo", recentemente trazida à tona em virtude da Deliberação ANBIMA no 45 de 08 de fevereiro de 2005 (que veio ratificar as disposições da antiga Deliberação ANBID no 29 de 20 de outubro de 2006) diz respeito aos fundos conhecidos como "raspa-conta".

Esse tipo de fundo, que possui aplicação e/ou resgate automáticos, de forma a remunerar saldo remanescente em conta corrente, existe apenas para aqueles classificados como "Curto Prazo" pela CVM e ANBIMA. Tendo em vista as os riscos inerentes à transferência dos recursos de uma instituição financeira para um fundo de investimento (especialmente no que tange à perda da garantia do FGC para pessoas físicas), a ANBIMA se apressou para limitar o acesso de investidores não qualificados ao produto, bem como listar uma série de avisos e obrigações que devem constar nos prospectos desses fundos.

Tal como ocorre em diversas Resoluções editadas pelo CMN, como por exemplo, no § 4은 do artigo 70 da Resolução CMN no 3.922 de 25 de novembro de 2010 (que dispõe sobre as aplicações dos recursos dos regimes próprios de previdência social instituídos pela União, Estados, Distrito Federal e Municípios): “Art. 7o No segmento de renda fixa, as aplicações dos recursos dos regimes próprios de previdência social subordinam-se aos seguintes limites: (...) VI - até 15\% (quinze por cento) em cotas de fundos de investimento em direitos creditórios, constituídos sob a forma de condomínio aberto; VII - até 5\% (cinco por cento) em: a) cotas de fundos de investimento em direitos creditórios, constituídos sob a forma de condomínio fechado; ou b) cotas de fundos de investimento classificados como renda fixa ou como referenciados em indicadores de desempenho de renda fixa que contenham em sua denominação a expressão "crédito privado". (...) \& 4 o As aplicações previstas no inciso VI e alínea "a" do inciso VII deste artigo subordinam-se a: I - que a série ou classe de cotas do fundo seja considerada de baixo risco de crédito, com base, dentre outros critérios, em classificação efetuada por agência classificadora de risco em funcionamento no País; (...)" (grifo nosso) 
- 1.6.2. Referenciado

Os fundos classificados como "Referenciados" devem atender cumulativamente as seguintes condições, nos termos do artigo 94 da ICVM no 409/04:

“I - tenham 80\% (oitenta por cento), no mínimo, de seu patrimônio líquido representado, isolada ou cumulativamente, por:

a) títulos de emissão do Tesouro Nacional ou do Banco Central do Brasil;

b) títulos e valores mobiliários de renda fixa cujo emissor esteja classificado na categoria baixo risco de crédito ou equivalente, com certificação por agência de classificação de risco localizada no País;

II - estipulem que 95\% (noventa e cinco por cento), no mínimo, da carteira seja composta por ativos financeiros de forma a acompanhar, direta ou indiretamente, a variação do indicador de desempenho ("benchmark") escolhido;

III - restrinjam a respectiva atuação nos mercados de derivativos a realização de operações com o objetivo de proteger posições detidas à vista, até o limite dessas."

Para que seja dada maior transparência aos investidores, o §2o estabelece que o indicador de desempenho deve estar expressamente definido na denominação do fundo, ou seja, por exemplo: "a moeda quando tiver como referência a taxa de câmbio do real com o dólar ou a do real com o euro; o IGP-M quando tiver como referência a variação do IGP-M; ou o DI quando tiver como referência a variação da taxa Selic ou da taxa dos depósitos interfinanceiros - DI"42.

Assim como ocorre para os fundos "Curto Prazo", é vedada a cobrança de taxa de performance, exceto quando se tratar de fundos destinados exclusivamente a investidores qualificados.

A título informativo, a ANBIMA vai além das restrições contidas na ICVM no 09/04 e estabelece que o montante não aplicado em operações que busquem acompanhar as variações dos parâmetros de referência deve ser direcionado apenas para operações permitidas para os fundos "Curto Prazo". 
- 1.6.3. Renda Fixa

Os fundos "Renda Fixa" são aqueles cujo principal fator de risco de sua carteira seja a variação da taxa de juros doméstica ou de índice de preços (ou ambos, se for o caso), de acordo com o artigo 95 da ICVM no 409/04.

Além disso, conforme já salientado ao longo do presente trabalho, devem alocar ao menos $80 \%$ (oitenta por cento) da carteira em títulos ou valores mobiliários relacionados diretamente (ou sintetizados via derivativos) ao fator de risco que dá nome à classe.

Com relação à vedação de cobrança de taxa de performance em fundos destinados ao público em geral, a CVM acrescentou mais uma exceção, de forma a permitir que a referida taxa seja cobrada na hipótese do fundo assumir o compromisso de obter o tratamento fiscal destinado a fundos de longo prazo previsto na regulamentação fiscal vigente.

A ANBIMA optou por destrinchar a classificação renda fixa, criando também as subdivisões "Crédito Livre" e "Índices", de acordo com os fatores de risco (crédito privado e indicadores de desempenho de renda fixa, respectivamente).

- 1.6.4. Cambial

O artigo 95-A da ICVM no 409/04, que trata dos fundos "Cambiais", dispõe:

“Art. 95-A. Os Fundos classificados como Cambiais deverão ter como principal fator de risco de sua carteira a variação de preços de moeda estrangeira, ou a variação do cupom cambial.

Parágrafo único. Nos fundos a que se refere o caput, no mínimo, $80 \%$ (oitenta por cento) da carteira deverá ser composta por ativos relacionados diretamente, ou sintetizados via derivativos, ao fator de risco que dá nome à classe." (grifo nosso)

Os fundos cambiais atrelados ao dólar voltaram a ficar em voga em virtude da forte valorização da moeda norte-americana no ano de 2011. 
De acordo com matéria publicada no jornal “O GLOBO” (versão impressa) em 26 de setembro de $2011^{43}$, a rentabilidade de alguns fundos dessa categoria chegou a $15 \%$ (quinze por cento) no ano.

Esse cenário é substancialmente influenciado pelas incertezas geradas pela atual crise na Europa, o que faz com que muitos investidores busquem abrigo em fundos cambiais.

Não obstante a ótima performance no ano corrente, é válido destacar que a aplicação em fundos cambiais é feita, em sua maioria, visando proteger o patrimônio de oscilações bruscas na cotação da moeda estrangeira (denominadas operações de hedge).

A diferença proposta pela classificação ANBIMA, nesse caso, limita-se a estabelecer que o montante não aplicado em ativos relacionados direta ou indiretamente ao dólar ou ao euro deve ser aplicado somente em títulos e operações de "Renda Fixa".

\section{- 1.6.5. Ações}

Nos termos do §1으 do artigo 95-B da ICVM no 409/04, a composição da carteira dos fundos de "Ação" deve observar os seguintes limites:

“I - 67\% (sessenta e sete por cento), no mínimo, de seu patrimônio líquido deverão ser compostos pelos seguintes ativos:

a) ações admitidas à negociação em bolsa de valores ou entidade do mercado de balcão organizado;

b) bônus ou recibos de subscrição e certificados de depósito de ações admitidas à negociação nas entidades referidas na alínea "a";

c) cotas de fundos de ações e cotas dos fundos de índice de ações negociadas nas entidades referidas na alínea "a"; e

d) Brazilian Depositary Receipts classificados como nível II e III, de acordo com o art. 3ㅇ, §1으, incisos II e III da Instrução CVM no 332, de 04 de abril de 2000."

Uma característica dos fundos de "Ação" (bem como dos "Multimercado", como se verá mais adiante) é a possibilidade do fundo, desde 
que devidamente previsto em Regulamento, ser dispensado de observar os limites gerais de concentração por emissor ${ }^{44}$ previstos na ICVM no 409/04.

Especificamente com relação aos fundos classificados de acordo com este item, observa-se que atualmente está excluído da exceção citada acima apenas um tipo de BDR (certificados de depósitos de ações de companhias estrangeiras emitidos e negociados no Brasil), qual seja, o de nível I, vide §3ㅇ do artigo 95-B.

Tal situação é explicada pelo fato do BDR nível I, ao contrário dos de nível II ou III, ser admitido à negociação em mercado de balcão não organizado, bem como dispensar o registro na CVM da companhia com sede no exterior, nos termos da ICVM no 332 de 4 de abril de 2000. Além disso, apenas a modalidade nível I admite a emissão de BDR não patrocinado (aquele no qual não há acordo entre a instituição depositária e a companhia emissora dos valores mobiliários objeto do certificado de depósito).

Ao que tudo indica, essa regra será alterada num futuro próximo, tendo em vista a publicação do Edital de Audiência Pública SDM no 11/11 da CVM, que pretende acabar com a referida limitação, para dar continuidade ao processo gradual de promoção do investimento no exterior que começou com a Instrução CVM no 450, de 30 de março de 2007.

Tendo em vista os inúmeros campos de atuação no mercado acionário, a ANBIMA procurou segmentar ao máximo a classificação dos fundos de ação, criando ao todo 10 subdivisões.

Dentre elas, merecem destaque aquelas que (i) se diferenciam pelo mandato do gestor (gestão passiva ou ativa em relação ao benchmark), (ii) privilegiam ações small caps, (iii) ações de empresas com histórico de dividend yield e, naturalmente, (iv) não observam qualquer restrição adicional à ICVM no 409/04 e atendem pela denominação "Ações Livre".

\section{- 1.6.6. Dívida Externa ${ }^{45}$}


Os fundos classificados como "Dívida Externa" aplicam, de acordo com o artigo 96 da ICVM no 409/04, "no mínimo, 80\% (oitenta por cento) de seu patrimônio líquido em títulos representativos da dívida externa de responsabilidade da União, sendo permitida a aplicação de até $20 \%$ (vinte por cento) do patrimônio líquido em outros títulos de crédito transacionados no mercado internacional".

Em virtude do disposto acima, é natural que esse tipo de fundo seja isento da obrigação de observar os limites gerais de concentração por emissor.

Por fim, ressalte-se que uma das maiores preocupações da CVM com essa classe é garantir que os serviços de custódia no exterior sejam realizados por autoridades devidamente reconhecidas internacionalmente, com o intuito de garantir a existência dos ativos, como demonstra os $\S \S 1$ e e 2 o do artigo supracitado:

“§1으 Os títulos representativos da dívida externa de responsabilidade da União devem ser mantidos, no exterior, em conta de custódia, no Sistema Euroclear ou na LuxClear - Central Securities Depositary of Luxembourg (CEDEL).

§2ㅇ Os títulos integrantes da carteira do fundo devem ser custodiados em entidades habilitadas a prestar esse serviço pela autoridade local competente."

\section{- 1.6.7. Multimercado}

São aqueles cuja política de investimento, nos termos do artigo $97 \mathrm{da}$ ICVM no 409/04, envolvem vários fatores de risco, sem o compromisso de concentração em nenhum fator em especial ou em fatores diferentes das demais classes.

Sem dúvida, essa é a classificação que garante maior liberdade ao gestor, tanto em relação a limites de concentração (por emissor e por modalidade de ativo) quanto à composição da carteira. 
Assim como os fundos de "Ações", podem dispensar a observância de determinados limites desde que respeitadas as obrigações contidas no $\S 3$ o do artigo 97.

Novamente a ANBIMA se preocupou em criar subdivisões (10 ao todo) para aumentar a transparência da estratégia de determinado fundo ao investidor que deseja investir na indústria. Passando pelas estratégias de "Long and Short" (Neutro ou Direcional, de acordo com a intenção do gestor de montar posições compradas e/ou vendidas através do uso de derivativos) e indo até a "Multimercado Multigestor" (indicada para fundos de cotas cuja especialidade é investir nos melhores fundos - geridos principalmente por outras casas disponíveis no mercado), a classificação ANBIMA cumpre de forma satisfatória seu papel.

\subsection{Principais prestadores de serviço}

Numa indústria que prima pela especialização, é comum (e, do ponto de vista de governança, aconselhável) que o fundo de investimento conte com diferentes prestadores de serviço para desempenhar as tarefas exigidas pela regulação.

\section{- 1.7.1. Administrador}

É figura central para os fundos de investimento, pois, de maneira ampla, compreende "o conjunto de serviços relacionados direta ou indiretamente ao funcionamento e à manutenção do fundo" (artigo 56 da ICVM no 409/04).

Como visto anteriormente, os fundos não gozam de personalidade jurídica, o que faz com que sejam representados em todos os atos formais pelo seu administrador. 
Tal relação tem início desde a constituição ${ }^{46}$ do fundo, pois cabe ao administrador elaborar uma deliberação (juntamente com o Regulamento) e registrá-la no cartório de títulos e documentos, nos termos do artigo 3으 da ICVM ำ 409/04.

Não obstante o rol do $\$ 1$ 을 do artigo 56 ser mais amplo, na maioria dos casos observa-se que os administradores acumulam as funções de (i) tesouraria, controle e processamento dos títulos e valores mobiliários, (ii) distribuição - em caráter não exclusivo -, e (iii) escrituração da emissão e resgate de cotas. Como se pode observar, todas elas são vitais para a boa existência do veículo.

Para desempenhar tal atividade, o administrador deve preencher os requisitos da ICVM no 306/99, além de seguir fielmente os preceitos dispostos no Capítulo VI da ICVM no 409/04 (que incluem, não se limitando, ao envio de informações periódicas aos cotistas, disponibilização dos registros do fundo à CVM, etc.).

\section{- 1.7.2. Gestor}

Por definição, gestão da carteira do fundo é "a gestão profissional, conforme estabelecido no seu regulamento, dos títulos e valores mobiliários dela integrantes, desempenhada por pessoa natural ou jurídica credenciada como administradora de carteira de valores mobiliários pela CVM, tendo o gestor poderes para negociar, em nome do fundo de investimento, os referidos títulos e valores mobiliários".

É o responsável direto da busca pela rentabilidade, escolhendo as estratégias a serem utilizadas e os ativos escolhidos para compor a carteira. Assim como o administrador, deve ser autorizado pela CVM através da ICVM no $306 / 99$.

\section{- 1.7.3. Custodiante}


A CVM obriga o administrador a contratar instituição para realizar os serviços de custódia do fundo caso ele, administrador, não seja credenciado perante a autarquia para tal fim.

A autorregulação também acompanha de perto a figura do Custodiante, que, nos termos do artigo 5o do Código ANBIMA de Regulação e Melhores Práticas dos Serviços Qualificados ao Mercado de Capitais, é responsável pela "liquidação física e financeira dos ativos, sua guarda, bem como a administração e informação de eventos associados a esses ativos".

Além disso, essa atividade compreende, também, a "liquidação financeira de derivativos, contratos de permutas de fluxos financeiros - swap e operações a termo, bem como o pagamento das taxas relativas ao Serviço prestado, tais como, mas não limitadas a, taxa de movimentação e registro dos depositários e câmaras e sistemas de liquidação".

\section{- 1.7.4. Distribuidor}

Os distribuidores não precisam dedicar exclusivamente a essa função, razão pela qual ressaltamos anteriormente que muitos administradores desempenham a atividade de distribuição em caráter não exclusivo para os respectivos fundos.

Em resumo, o papel deles é eminentemente comercial, ou seja, atuam angariando investidores para os fundos de investimento, e em contrapartida recebem uma remuneração (conhecida como "rebate", que representa porcentagens das taxas de administração/performance geradas pelos clientes apresentados). Dessa forma, cresce a capilaridade da indústria de fundos na sociedade, pois os distribuidores somam força com as já existentes equipes de venda dos fundos na divulgação dos produtos.

Muitas das vezes, os clientes dos distribuidores são fundos administrados/geridos por eles próprios. Essa estrutura permite que as respectivas áreas de alocação (funds of funds) obtenham receitas adicionais ao aplicar nos fundos mais consagrados do mercado. 


\section{- 1.7.5. Divisão de responsabilidades}

De acordo com o §5으 do artigo 57 da ICVM n 409/04, o administrador e todos os prestadores com os quais tenha contratado respondem perante a CVM, na esfera de suas competências, por seus próprios atos e omissões contrários à lei, ao regulamento do fundo e às demais disposições regulamentares.

Definem-se, nesse dispositivo, os limites da responsabilidade administrativa dos prestadores de serviço para os fundos, ou seja, aquela decorrente, por exemplo, da instauração de processos sancionadores por parte da equipe de fiscalização da CVM.

Já o §5 do artigo 57 da ICVM no 409/04 dispõe que:

“§ 2 ㅇ Os contratos firmados na forma do $\S 1$, referentes aos serviços prestados nos incisos I, III e $\mathrm{V}^{47}$ do $\S 1$ o do art. 56, deverão conter cláusula que estipule a responsabilidade solidária entre o administrador do fundo e os terceiros contratados pelo fundo, por eventuais prejuízos causados aos cotistas em virtude das condutas contrárias à lei, ao regulamento e aos atos normativos expedidos pela CVM."

Percebe-se que a Instrução trata, nesse ponto, da responsabilidade civil, respeitando o princípio constante no artigo 265 do Código Civil ("a solidariedade não se presume; resulta da lei ou da vontade das partes"), razão pela qual impôs aos prestadores de serviço a inclusão de cláusula de solidariedade nos contratos para que os acordos possam ser regularmente celebrados.

Isso não afasta, contudo, a responsabilidade do administrador por prejuízos decorrentes de atos e omissões próprios a que der causa, conforme §3으 do referido artigo.

A jurisprudência brasileira ainda é muito escassa em matérias relativas aos fundos de investimento. Infelizmente, a maioria dos casos julgados pelos tribunais remete a litígios instaurados no final da década de 90, época da maxidesvalorização da moeda brasileira (gerando perdas para os cotistas), o que 
faz com que as decisões privilegiem discussões acerca da ocorrência de caso fortuito ou força maior.

Recentemente, porém, um caso envolvendo a gestora de recursos GWI Consultoria, Participações e Serviços Ltda. ("GWI”) pode ser útil aos operadores do Direito, servindo como leading case de matérias até então pouco ventiladas na esfera judicial.

Conforme amplamente noticiado pela mídia especializada, fundos geridos pela referida instituição tiveram que ser fechados para aplicações e resgates pela respectiva administradora (no caso, BNY Mellon), que seguiu a orientação do artigo 16 da ICVM no 409/04:

"Art. 16. Em casos excepcionais de iliquidez dos ativos componentes da carteira do fundo, inclusive em decorrência de pedidos de resgates incompatíveis com a liquidez existente, ou que possam implicar alteração do tratamento tributário do fundo ou do conjunto dos cotistas, em prejuízo destes últimos, o administrador poderá declarar o fechamento do fundo para a realização de resgates, sendo obrigatória a convocação de Assembléia Geral Extraordinária, no prazo máximo de 1 (um) dia, para deliberar, no prazo de 15 (quinze) dias, a contar da data do fechamento para resgate, sobre as seguintes possibilidades:

I - substituição do administrador, do gestor ou de ambos;

II - reabertura ou manutenção do fechamento do fundo para resgate;

III - possibilidade do pagamento de resgate em títulos e valores mobiliários;

IV - cisão do fundo; e

V - liquidação do fundo."

Tal medida foi tomada em virtude da forte queda no valor das cotas dos fundos em virtude das oscilações recentes do mercado global. Um dos fundos, inclusive, chegou a apresentar patrimônio líquido negativo, sendo que seus cotistas (nos termos do artigo 13 da ICVM no 409/04) foram chamados a aportar recursos adicionais para adimplir com as obrigações contraídas.

Uma das principais causas da queda de rendimento dos fundos da GWI é a estratégia de gestão extremamente agressiva, com forte concentração em ativos de poucos emissores (tais como papéis emitidos pela Mafrig).

As principais lições que, futuramente, poderão ser tiradas desse caso são: 
1 - Tendo em vista que, até onde se tem notícia (matéria assinada por Luciana Monteiro e Angelo Pavini, divulgada em 30 de agosto de 2011 pelo jornal Valor Econômico ${ }^{48}$ ), os cotistas não cumpriram com o chamado para aporte de recursos adicionais, o caso pode desembocar no Poder Judiciário. Caso isto ocorra, teremos o primeiro precedente de cobrança judicial de cotistas de fundos, ocasião na qual fatalmente o conceito de natureza condominial dos fundos precisará ser discutido para solucionar a proporcionalidade do rateio entre os cotistas; e

2 - Ainda que o fundo seja destinado a investidores qualificados com investimento mínimo de $\mathrm{R} \$ 10.000 .000,00$ (o que faz com que o Regulamento seja amplamente liberal, permitindo que o gestor adote as mais variadas estratégias, com poucos limites formais), é possível que a conduta dos gestores seja questionada (imperícia/imprudência). Nessa hipótese, observaríamos na prática se o Poder Judiciário vai abordar de forma juridicamente correta a divisão de responsabilidades entre os prestadores de serviço, que, no caso de "gestor $x$ administrador", é solidária perante o cotista.

Aguardemos os próximos capítulos.

\subsection{Aspectos tributários}

Conforme dito anteriormente, a inscrição dos fundos no CNPJ/MF tem o condão de facilitar a sua identificação perante terceiros, como, por exemplo, no processo de abertura de contas nas corretoras que executarão as ordens emitidas pelas pessoas autorizadas pelo gestor. O maior desdobramento do CNPJ/MF, porém, ocorre na identificação do fundo perante a Receita Federal do Brasil ("RFB").

As operações realizadas no âmbito da carteira dos fundos são isentas de imposto de renda (“IR"). Nesse sentido, cabe a nós avaliar os reflexos do cenário acima no nível dos cotistas, já que estes são os beneficiários finais das aplicações 
e, no caso da indústria de fundos de investimento regulados pela ICVM no 409/04, os únicos responsáveis por arcar com os ônus fiscais para que seja evitada uma dupla tributação.

Os cotistas podem ter seus rendimentos sujeitos a dois impostos: Imposto sobre Operações de Crédito, Câmbio e Seguro, ou relativas a Títulos ou Valores Mobiliários (“IOF") e IR.

O primeiro representa nítida intervenção do Estado no ambiente econômico, pois os valores da alíquota que incidem no rendimento de cotistas variam regressivamente, partindo de $96 \%$ para aqueles que resgatam no primeiro dia útil subsequente ao da aplicação, até $0 \%$ para aqueles que resgatam a partir do trigésimo dia da data da aplicação. Resta evidente o objetivo do legislador de incentivar os investimentos de longo prazo, "punindo" aqueles que acessam ao mercado com fins especulativos de curtíssimo prazo.

O segundo, por sua vez, reveste-se, também, de caráter arrecadatório. A Instrução Normativa da RFB no 1.022 de 05 de abril de 2010 (“IN RFB no 1.022") reuniu num só diploma todas as regras atinentes à matéria sendo que a ICVM no 409/04 apenas obriga o administrador do fundo a divulgar (no regulamento e prospecto) qual o tratamento tributário aplicável ao fundo.

É interessante notar que a IN RFB № 1.022 utiliza nomenclatura própria, que muitas vezes se confunde com as utilizadas pela CVM. Cabe a nós, nesse momento, explicar e - quando houver necessidade - distinguir os principais conceitos.

Para a RFB, os fundos tributados como "Longo Prazo - RFB" seriam aqueles cuja carteira de títulos tenha prazo médio superior a 365 (trezentos e sessenta e cinco) dias, sendo que os de "Curto Prazo - RFB" deveriam apresentar na carteira títulos com prazo médio igual ou inferior a 365 (trezentos e sessenta e cinco) dias (Art. 3o IN RFB 1022) ${ }^{49}$. baseados numa média móvel de 40 dias (conforme detalhado nos $\S \S 60$ e seguintes do Art. 18 da IN RFB no1022), e não diariamente como ocorre, por exemplo, com os limites de concentração por modalidade de ativo dos fundos regidos pela ICVM no 409/04. 
Para a CVM, os fundos de "Longo Prazo - CVM" são aqueles que assumem o compromisso de obter o tratamento fiscal destinado aos fundos de "Longo Prazo - RFB" previsto na regulamentação fiscal vigente (vide artigo 92, §1으, da ICVM no 409/04). Já para caracterizar um fundo como "Curto Prazo - CVM", ela leva em consideração outros parâmetros, diferentes dos abordados pela RFB, conforme exposto no caput do Art. 93:

"Art. 93. Os fundos classificados como "Curto Prazo" deverão aplicar seus recursos exclusivamente em títulos públicos federais ou privados pré-fixados ou indexados à taxa SELIC ou a outra taxa de juros, ou títulos indexados a índices de preços, com prazo máximo a decorrer de 375 (trezentos e setenta e cinco) dias, e prazo médio da carteira do fundo inferior a 60 (sessenta) dias, sendo permitida a utilização de derivativos somente para proteção da carteira e a realização de operações compromissadas lastreadas em títulos públicos federais."

Além disso, o compartilhamento de expressões similares atinge também os fundos de ações. Enquanto para a CVM os "Fundos de Ações - CVM" são aqueles que seguem a composição de carteira prevista no $§ 10$ do artigo 95-B da ICVM no 409/04, a RFB adota critérios próprios (porém similares) e determina:

“Art. 18. (...)

$\S$ 2o Para efeito do disposto neste artigo, consideram-se fundos de investimento em ações aqueles cujas carteiras sejam constituídas, no mínimo, por $\mathbf{6 7 \%}$ (sessenta e sete por cento) de ações negociadas no mercado à vista de bolsa de valores ou entidade assemelhada, no País ou no exterior, na forma regulamentada pela Comissão de Valores Mobiliários.

$\S 3$ ㅇ Para efeito da proporção de que trata o $\S 2^{\circ}$, serão equiparados às ações:

I - no Brasil:

a) os recibos de subscrição;

b) os certificados de depósito de ações;

c) os Certificados de Depósito de Valores Mobiliários (Brazilian Depositary Receipts - BDR);

d) as cotas dos fundos de ações; $\mathrm{e}$

e) as cotas dos fundos de índice de ações negociadas em bolsa de valores ou mercado de balcão organizado;

II - no exterior:

a) os American Depositary Receipts (ADR); e

b) os Global Depositary Receipts (GDR)." (grifo nosso)

A título de curiosidade, é possível que tenhamos uma situação ao menos inusitada, qual seja, um fundo de investimento em cotas de fundo de 
investimento multimercado (de acordo com a classificação CVM do artigo 97 da ICVM no 409/04) sendo tributado como "Fundo de Ações - RFB". Bastaria, nesse caso, que sua carteira estivesse adequada ao disposto na IN RFB 1.022, ou seja, direcionada para aplicação apenas em um FIA, por exemplo ${ }^{50}$.

As alíquotas aplicáveis (que serão explicadas em seguida), de acordo com os artigos 6우 7으, 8으, 9으 e 18 da IN RFB № 1.022, podem ser sistematizadas da seguinte forma:

(i) Longo Prazo

\begin{tabular}{|l|c|c|c|}
\hline Prazo do investimento & IR semestral & IR complementar & IR total \\
\hline Até 180 dias & $15 \%$ & $7,5 \%$ & $22,5 \%$ \\
\hline Até 360 dias & $15 \%$ & $5 \%$ & $20 \%$ \\
\hline De 361 até 720 dias & $15 \%$ & $2,5 \%$ & $17,5 \%$ \\
\hline Acima de 720 dias & $15 \%$ & N/A & $15 \%$ \\
\hline
\end{tabular}

(i) Curto Prazo

\begin{tabular}{|l|c|c|c|}
\hline Prazo do investimento & IR semestral & IR complementar & IR total \\
\hline Até 180 dias & $20 \%$ & $2,5 \%$ & $22,5 \%$ \\
\hline Acima de 360 dias & $20 \%$ & N/A & $20 \%$ \\
\hline
\end{tabular}

(i) Ações

\begin{tabular}{|l|c|c|c|}
\hline Prazo do investimento & IR semestral & IR complementar & IR total \\
\hline Qualquer & N/A & $15 \%$ & $15 \%$ \\
\hline
\end{tabular}

Em breve resumo, a IN RFB 1.022 utiliza mecanismos parecidos com aqueles utilizados no caso do IOF, através dos quais o Estado incentiva investimentos de longo prazo, que na maioria dos casos são recepcionados de maneira mais efetiva pela economia de um país. 
Para isso, o diploma estabelece alíquotas regressivas de IR, variando conforme o prazo das aplicações nos fundos. O momento de cobrança das mesmas, porém, é motivo de debates no mundo jurídico.

O artigo 9ㅇ da IN RFB no 1.022 prevê que a modalidade conhecida como "come cotas", na qual o cotista observa redução na quantidade das suas cotas nos últimos dias de maio e novembro de cada ano (ou no resgate, caso tenha ocorrido em data anterior) em valor correspondente a $15 \%$ ou $20 \%$ (para fundos de longo e curto prazo, respectivamente) sobre os rendimentos auferidos no período ${ }^{51}$. Ressalte-se que os fundos de "Ações - RFB" não estão sujeitos a esse recolhimento semestral.

O objetivo da antecipação promovida pelo legislador é evitar que seja postergado ad eternum o recolhimento do imposto que fatalmente seria devido quando do resgate das cotas. Não chega a ocorrer uma distribuição de rendimentos pelo administrador ${ }^{52}$ seguida de recolhimento do IR, mas sim redução semestral na quantidade das cotas dos cotistas proporcionalmente à alíquota aplicável.

Adicionalmente, nos termos do §2을 do artigo 9 da IN RFB nํ 1.022, por ocasião do resgate das cotas aplica-se a alíquota complementar correspondente, conforme explicitado nos quadros acima ("IR complementar").

Podemos sintetizar as discussões doutrinárias relativas ao sistema do "come cotas" através do posicionamento de ANDREA NOGUEIRA NEVES:

"A forma de tributação dos fundos de renda fixa, apelidada como 'come-cotas', mereceria todas as críticas por si só, uma vez que, ao mudar o momento da incidência do imposto de renda (...), representa total inobservância, por parte do legislador, dos requisitos para caracterização da renda e da disponibilidade econômica pelo contribuinte. ${ }^{153}$ (grifo nosso)

A sistemática do "come cotas" não se aplica aos fundos fechados.

O administrador é o responsável tributário pelo recolhimento na fonte dos tributos devidos pelos cotistas. Exceção à regra se dá nos casos de aplicação por "conta e ordem", onde a obrigação é repassada para a instituição intermediadora (inciso XI do artigo 36 da ICVM no 409/04 c/c inciso II do artigo 17 da IN RFB n 1022).

53

NEVES, Andrea Nogueira. Considerações sobre a tributação dos fundos de investimento fechados. In: MOSQUERA, Roberto Quiroga (Org.). O direito Tributário e o mercado financeiro e de capitais. São Paulo: Dialética, 2009. p. 72. 
De fato, não se verifica a disponibilidade econômica ou jurídica da renda (fato gerador do IR) para o cotista quando nos períodos de cobrança do "come cotas", já que ele não chega a poder exercer as prerrogativas decorrentes do direito de propriedade previstas no Código Civil. 


\section{Desenvolvimento}

\subsection{Taxas e despesas}

Para sustentar o bom funcionamento do fundo de investimento, faz-se necessária a cobrança de taxas e/ou encargos, tanto sobre patrimônio líquido do fundo como um todo, quanto em relação aos cotistas individualmente.

Os recursos decorrentes do recolhimento destes custos possuem diversos fins, variando de acordo com a natureza de cada uma das cobranças; podem ser destinados, por exemplo, para (i) a remuneração dos prestadores de serviço, (ii) o adimplemento de obrigações referentes ao registro e manutenção do fundo perante os órgãos públicos, reguladores e autorreguladores, ou (iii) integrar o próprio patrimônio do fundo.

O objetivo do capítulo é expor as características das principais despesas para, posteriormente, analisar com maior profundidade a taxa de performance, utilizando como plano de fundo a recente decisão do Colegiado da CVM no Processo Administrativo no 2010/3326.

\section{- 2.1.1. Taxa de ingresso e saída}

As taxas de ingresso e saída, quando previstas no Regulamento do fundo (nos termos do inciso VIII do artigo 41 da ICVM no 409/04), são suportadas individualmente pelo cotista.

A primeira incide no momento do aporte dos recursos, enquanto a segunda - como o próprio nome indica - aparece quando o cotista solicita o resgate do fundo.

Levando-se em consideração a dinâmica do mercado de arrecadar a maior quantidade possível de recursos, é simples concluir que a taxa de ingresso (que impõe barreiras à captação dos fundos) é menos comum que a de saída.

A maioria dos Regulamentos que prevê a cobrança de taxa de saída estabelece períodos distintos para a conversão das cotas e o pagamento do 
resgate. Nesse sentido, é dado o direito do cotista obter seu dinheiro de maneira mais célere (isto é, sem a necessidade de observar o prazo de resgate padrão) desde que seja descontado um percentual pré-estabelecido do valor resgatado.

Explica-se: ainda que haja um controle constante para adequar a liquidez da carteira do fundo aos seus prazos de resgate, algumas solicitações de resgate podem atingir valores relevantes, obrigando o Gestor a desmontar posições cujas estratégias foram idealizadas levando-se em consideração um determinado montante de patrimônio líquido. Para minimizar os efeitos negativos decorrentes de solicitações de resgate até certo ponto "inesperadas", o valor cobrado a título de taxa de saída é integralmente revertido para o fundo.

Tendo em vista a sua relevância para o investidor, o aumento das taxas de ingresso e saída só entrará em vigor 30 (trinta) dias após a aprovação da Assembleia Geral de Cotistas, de acordo com o inciso I do parágrafo único do artigo 43.

\section{- 2.1.2. Encargos}

Os encargos são as despesas listadas no artigo 99 da ICVM no 409/04 que podem ser debitadas diretamente do patrimônio do fundo. É importante notar que o referido artigo representa uma lista numerus clausus, isto é, tem o condão de abranger todas as hipóteses que podem ser enquadradas no conceito de "encargos".

\footnotetext{
"Art. 99. Constituem encargos do fundo as seguintes despesas, que the podem ser debitadas diretamente:

I - taxas, impostos ou contribuições federais, estaduais, municipais ou autárquicas, que recaiam ou venham a recair sobre os bens, direitos e obrigações do fundo;

II - despesas com o registro de documentos em cartório, impressão, expedição e publicação de relatórios e informações periódicas previstas nesta Instrução;

III - despesas com correspondência de interesse do fundo, inclusive comunicações aos cotistas;

IV - honorários e despesas do auditor independente;

$\mathrm{V}$-emolumentos e comissões pagas por operações do fundo;

VI - honorários de advogado, custas e despesas processuais correlatas, incorridas em razão de defesa dos interesses do fundo, em juízo ou fora dele, inclusive o valor da condenação imputada ao fundo, se for o caso;
} 
VII - parcela de prejuízos não coberta por apólices de seguro e não decorrente diretamente de culpa ou dolo dos prestadores dos serviços de administração no exercício de suas respectivas funções;

VIII - despesas relacionadas, direta ou indiretamente, ao exercício de direito de voto do fundo pelo administrador ou por seus representantes legalmente constituídos, em assembleias gerais das companhias nas quais o fundo detenha participação;

IX - despesas com custódia e liquidação de operações com títulos e valores mobiliários, ativos financeiros e modalidades operacionais;

$X$ - despesas com fechamento de câmbio, vinculadas às suas operações ou com certificados ou recibos de depósito de valores mobiliários;

$\mathrm{XI}$ - no caso de fundo fechado, a contribuição anual devida às bolsas de valores ou às entidades do mercado de balcão organizado em que o fundo tenha suas cotas admitidas à negociação; $\mathrm{e}$

XII - as taxas de administração e de performance, conforme previsto no art.61;"

A taxatividade do rol de encargos pode ser corroborada pela leitura do artigo 100, que dispõe que quaisquer despesas não previstas como encargos do fundo, inclusive as relativas à elaboração do prospecto, correm por conta do administrador, devendo ser por ele contratados.

A prática, no entanto, nos revela que na maioria dos Contratos de Gestão (isto é, o instrumento que formaliza a contratação do Gestor pelo fundo, representado pelo seu Administrador) as despesas extraordinárias correm por conta do Gestor, tais como o pagamento da taxa anual cobrada pela ANBIMA.

A noção passada pelo artigo 99 é que são consideradas como encargos todas as despesas ordinárias, do dia a dia do fundo, sem as quais os prestadores de serviço dos fundos não poderiam, por exemplo, abrir contas em corretoras para operar os ativos da carteira, ou, ainda, enviar/postar correspondências aos cotistas.

Do artigo transcrito acima, destaque para o inciso VIII, que trata do proxy voting, prática historicamente estimulada pela CVM e ANBIMA na qual o Administrador (ou seus representantes legalmente constituídos, nos termos do inciso II do artigo 40) tem o poder-dever de comparecer às eventuais assembleias das companhias das quais o fundo detenha participação a exercer o direito de voto no melhor interesse dos cotistas. 
O Edital de Audiência Pública SDM no 06/11 54 , com bastante propriedade e refletindo a realidade do mercado, propõe (i) a inclusão do Gestor na lista de agentes autorizados a representar o fundo nessas assembleias, o que nos parece lógico tendo em vista que é ele quem está mais próximo das atividades típicas de gestão, e (ii) uma nova redação para esclarecer que a política de voto pode ser exercida em relação a qualquer outro ativo detido pelo fundo, como as debêntures.

Dentre a lista de despesas previstas como encargos, faz-se necessário aprofundar o estudo em relação àquelas citadas no inciso XII, quais sejam: taxa de administração e performance.

\section{- 2.1.3. Taxa de Administração}

A taxa de administração é utilizada para remunerar os prestadores dos serviços listados nos incisos I a V do artigo 56 da ICVM no 409/04: gestão da carteira; consultoria de investimentos; tesouraria, controle e processamento dos ativos; distribuição das cotas; e escrituração da emissão e resgate das cotas.

De acordo com o inciso VII do artigo 41, ela precisa, via de regra, ser expressa em percentual anual do patrimônio líquido (base 252 dias) para que o investidor tenha uma segurança do máximo que pode ser descontado da sua cota. Essa forma de cálculo faz com que a taxa de administração tenha um peso considerável na rentabilidade final do fundo, devendo ser um dos primeiros requisitos a ser observado por potenciais investidores no momento de analisar as opções do mercado.

No Processo Administrativo CVM no RJ 2008/1974 (que analisou, dentre outros itens, a possibilidade do Regulamento estabelecer um piso fixo em dinheiro a ser cobrado alternativamente ao percentual anual do patrimônio líquido, entre os dois o de maior valor), o Diretor-Relator OTAVIO YAZBEK prolatou voto explicitando uma das razões que levaram a CVM a estabelecer que a taxa de administração deva ser expressa da forma indicada no artigo 41: 
“(...) entendo que a regra em questão tem como objetivo não apenas impedir que a taxa de administração possa variar a critério da instituição administradora mas, também, assegurar maior transparência para o público investidor de varejo, criando padrões que permitam a comparação entre as taxas de administração cobradas pelos diversos veículos. ${ }^{155}$ (grifo nosso)

Com relação à maneira pela qual o Administrador obtém o valor final da taxa, dispõe o §3ㅇ do artigo 62 que ela deve ser provisionada por dia útil, sempre como despesa do fundo e apropriada conforme estabelecido no regulamento. $\mathrm{O}$ mais comum no mercado, sem dúvidas, é o pagamento em bases mensais.

Ainda que não haja um limite máximo explícito que possa ser cobrado a título de taxa de administração, algumas decisões da CVM (dentre as quais destacamos os Processos Administrativos no RJ2009/6757 e RJ2009/5412) determinam que esse valor não pode ser alto o bastante a ponto de descolar a rentabilidade do fundo do seu respectivo benchmark.

Um dos principais argumentos realçados pelos Relatores de ambos os casos é que a leitura conjunta do $\$ 2$ 을 do artigo 62 com o inciso I do artigo 65-A transcritos abaixo - impõe um poder-dever ao Administrador do fundo de atuar de ofício (seguido de comunicação imediata aos cotistas e à própria CVM) para garantir que a alta taxa de administração não se transforme num obstáculo ao cumprimento do objetivo previsto no Regulamento:

"Art. 61. O regulamento deve dispor sobre a taxa de administração, que remunerará todos os serviços indicados nos incisos I a V do $\S 1$ 일 do art. 56, podendo haver remuneração baseada no resultado do fundo (taxa de performance) nos termos desta Instrução, bem como taxa de ingresso e saída.

(...)

$\S 2^{\circ}$ As taxas previstas no caput não podem ser aumentadas sem prévia aprovação da assembléia geral, mas podem ser reduzidas unilateralmente pelo administrador, que deve comunicar esse fato, de imediato, à CVM e aos cotistas, promovendo a devida alteração no regulamento e, se for o caso, no prospecto.

(...)

Art. $65-$ A. $\mathbf{0}$ administrador e $\mathbf{o}$ gestor estão obrigados a adotar as seguintes normas de conduta: 
I - exercer suas atividades buscando sempre as melhores condições para o

fundo, empregando o cuidado e a diligência que todo homem ativo e probo costuma dispensar à administração de seus próprios negócios, atuando com lealdade em relação aos interesses dos cotistas e do fundo, evitando práticas que possam ferir a relação fiduciária com eles mantida, e respondendo por quaisquer infrações ou irregularidades que venham a ser cometidas sob sua administração ou gestão;" (grifo nosso)

Por fim, é válido destacar que os fundos destinados a investidores qualificados podem, com fulcro no inciso III do artigo 110 da ICVM no 409/04, cobrar taxa de administração conforme estabelecido no Regulamento.

\subsection{Taxa de Performance - Processo Administrativo no $2010 / 3326$}

O caput do artigo 61 prevê a possibilidade de cobrança de taxa de performance pelo fundo de investimento, cujo papel seria premiar o Gestor pelos rendimentos aferidos num determinado período que excederem o benchmark.

Os requisitos gerais impostos pela CVM em relação à taxa de performance aparecem no $3^{\circ}$ do artigo 61 e no artigo 62, e estabelecem que ela deve ser (i) provisionada por dia útil e como despesa, (ii) vinculada a um parâmetro de referência compatível com a política de investimento, (iii) vinculada exclusivamente a percentuais superiores a $100 \%$ do parâmetro escolhido, (iv) cobrada ao menos semestralmente, apenas quando o valor da cota for superior àquele da última cobrança, e após deduzidas todas as demais despesas.

\footnotetext{
"Art. 61. O regulamento deve dispor sobre a taxa de administração, que remunerará todos os serviços indicados nos incisos I a V do $\S 1$ o do art. 56, podendo haver remuneração baseada no resultado do fundo (taxa de performance) nos termos desta Instrução, bem como taxa de ingresso e saída.

(...)

§3 os fundos abertos, as taxas de administração e de performance devem ser provisionadas por dia útil, sempre como despesa do fundo e apropriadas conforme estabelecido no regulamento.
}

(...) 
Art. 62. O regulamento poderá estabelecer a cobrança da taxa de performance, ressalvada a vedação de que tratam os arts. 93, 94 e 95.

§1ㅇ A cobrança da taxa de performance deve atender aos seguintes critérios:

I - vinculação a um parâmetro de referência compatível com a política de investimento do fundo e com os títulos que efetivamente a componham;

II - vedação da vinculação da taxa de performance a percentuais inferiores a $100 \%$ do parâmetro de referência;

III - cobrança por período, no mínimo, semestral; e

IV - cobrança após a dedução de todas as despesas, inclusive da taxa de administração.

§2을 Ressalvado o disposto no parágrafo 4을 deste artigo, é vedada a cobrança de taxa de performance quando o valor da cota do fundo for inferior ao seu valor por ocasião da última cobrança efetuada.

§3 É permitida a cobrança de ajuste sobre a performance individual do cotista que aplicar recursos no fundo posteriormente à data da última cobrança, exclusivamente nos casos em que o valor da cota adquirida for inferior ao valor da mesma na data da última cobrança de performance efetuada.

$\S 4$ O Os fundos destinados exclusivamente a investidores qualificados podem cobrar taxa de performance de acordo com o que dispuser o seu regulamento, estando dispensados de observar o disposto neste artigo."

No dia 31 de maio de 2011, foi publicada no site da CVM a decisão do Processo Administrativo № 2010/3326 que pode ser considerada o leading case da matéria, pois levanta o debate a respeito de conceitos fundamentais do instituto, além de expor - pela primeira vez após a edição da ICVM no 409/04 e alterações posteriores - a interpretação completa da CVM sobre a matéria.

\section{- 2.2.1 Posicionamento da CVM}

Ao realizar pesquisas por amostragem (denominadas de roteiros de inspeção) nos fundos de investimento disponíveis no mercado, a Gerência de Acompanhamento de Fundos (diretamente vinculada à Superintendência de Relações com Investidores Institucionais - SIN) oficiou certo administrador de fundos de investimentos, a BBM Administração de Recursos DTVM S.A., na qualidade de administradora do fundo BBM Fermat FIA ("Fundo"), solicitando ajuste na redação do artigo 13 do Regulamento, em especial no seu §1ㅇ:

“ARTIGO 13

O GESTOR fará jus, ainda, ao recebimento da taxa de performance de $20 \%$ (vinte por cento) do rendimento das cotas do FUNDO que exceder a $100 \%$ (cem por cento) da variação diária do IBrX-100 - Índice Brasil de fechamento, divulgado 
diariamente pela Bolsa de Valores de São Paulo (o "benchmark"), já descontada a remuneração referida no artigo anterior. Não será devida a taxa de performance quando o valor da cota for inferior ao seu valor por ocasião de sua última cobrança efetuada ou, se esta não tiver ocorrido, da data de aquisição das cotas.

PARÁGRAFO 1음

A taxa de performance será provisionada diariamente e calculada individualmente em relação a cada aquisição de cotas por cada cotista.

PARÁGRAFO 2음

As datas-base para o efeito de aferição da taxa de performance corresponderão ao primeiro dia útil dos meses de janeiro e julho de cada ano.

PARÁGRAFO 3음

Para efeito de cálculo da taxa de performance será considerado como início do período a última data-base utilizada para a aferição da taxa de performance. Caso este não tenha ocorrido, será utilizada a data de aquisição das cotas. Como término do período será utilizada a respectiva data-base ou o resgate das cotas, o que ocorrer primeiro.

\section{PARÁGRAFO 4음}

O valor devido como taxa de performance será pago semestralmente, no 5o (quinto) dia útil do mês de janeiro e no 5 o (quinto) dia útil do mês de julho de cada ano, ou no resgate das cotas, o que ocorrer primeiro." ${ }^{\prime 56}$ (grifo nosso)

Segundo os analistas da CVM, o fato da ICVM no 409/04 incluir a taxa de performance na lista de Encargos implica em não haver respaldo regulatório para o cálculo individual em relação a cada aquisição de cotas.

Tal raciocínio apoia-se na linha adotada pelo artigo 99 do referido normativo, posto que, conforme explicado anteriormente, os encargos são despesas e que devem ser debitada diretamente do fundo.

Nesse sentido, a interpretação mais adequada do artigo 61 seria aquela que toma como base o resultado do fundo como um todo, e não a valorização particular das cotas. Como será demonstrado a seguir, a diferença entre a aplicação de cada um dos entendimentos gera consequências diametralmente opostas. 
Caso contrário, estaria sendo admitida, na visão da área técnica da CVM, a possibilidade de "cobrança indireta de taxa de performance sobre cotistas que não teriam motivos para pagá-la", ou seja, "alguns investidores que não obtiveram rentabilidade pagam indiretamente a performance através da redução do valor de suas cotas, tendo em vista que essa despesa reduz o patrimônio líquido do fundo".

Argumenta o Diretor-Relator OTÁVIO YAZBEK que o sigilo imposto pela legislação aos administradores de fundos de investimentos no que concerne aos extratos individuais de cada cotista impossibilita o controle externo (seja da CVM, do mercado ou do próprio cotista) da conta que resultou no abatimento semestral no montante " $x$ " da cota de cada um dos investidores.

Por fim, deve-se levar em consideração o fato do Fundo ser destinado ao público em geral (varejo). Se estivéssemos tratando de público alvo restrito a investidores qualificados, não haveria que se falar em qualquer tipo de questionamento por parte da CVM, já que os fundos destinados exclusivamente qualificados podem cobrar taxa de performance de acordo com o que dispuser o seu regulamento (vide §4으 do artigo 61 da ICVM no 409/04).

\section{- 2.2.2. Argumentos a favor do cálculo individual}

A primeira (e talvez principal) questão a ser abordada diz respeito à correta interpretação do fato da taxa de performance ser vinculada ao resultado do fundo. É preciso separar a forma de apuração da taxa de administração daquela utilizada para a taxa de performance, ainda que a interpretação perfunctória da ICVM no 409/04 não faça essa distinção.

$\mathrm{Na}$ primeira, a conta é objetiva: verifica-se diariamente o patrimônio líquido total do fundo, aplicando o percentual previsto em Regulamento e provisionando a despesa que será paga no final do período pré-determinado através da diminuição no valor de cata cota.

Na segunda, porém, é preciso entender e valorar certas externalidades que indubitavelmente afetam o caso concreto, como, por exemplo, a 
possibilidade dos cotistas realizarem movimentações ao longo do período de aferição.

O objetivo da taxa de performance é recompensar a habilidade do Gestor de valorização das cotas através do manejo dos recursos que estavam a sua disposição naquele momento, utilizando estratégias em consonância com a política de investimentos descrita na documentação cadastral (Regulamento e Prospecto).

Não se pode relacionar o "desempenho do fundo" única e exclusivamente à sua variação patrimonial, já que fundos abertos admitem, por natureza, a possibilidade de aportes e/ou resgates a qualquer momento, de acordo com o artigo 5o da ICVM no 409/04:

"Art. 5o $\mathrm{O}$ fundo pode ser constituído sob a forma de condomínio aberto, em que os cotistas podem solicitar o resgate de suas cotas a qualquer tempo, ou fechado, em que as cotas somente são resgatadas ao término do prazo de duração do fundo." (grifo nosso)

A consequência lógica da interpretação conjunta da regra acima com a obrigatoriedade de provisionamento por dia útil é que o resultado econômico dos investimentos dos cotistas pode ser diferente (positivo ou negativo, em termos de valorização) dependendo do momento no qual eles ingressaram ou resgataram recursos do fundo (desde a data-base que dá início ao cálculo ou no meio do período de aferição, por exemplo).

Nesse sentido, o argumento de que "o resultado de um fundo" a partir do qual seria calculada a taxa de performance deveria levar em conta a valorização/depreciação de cada cota nos parece absolutamente compatível com a regra geral disposta no artigo 61 da ICVM no 409/04.

O supracitado artigo prevê que a taxa de performance (i) deve ser paga como despesa do fundo, e (ii) não pode ser cobrada quando o valor da cota for inferior ao seu valor por ocasião da última cobrança efetuada, sem esclarecer, portanto, o método pelo qual deve ser calculado o valor devido. 
Conclui-se, então, que as regras expressas no Regulamento do Fundo não ferem a regulamentação vigente, pois atendem a todos os requisitos mínimos previstos na ICVM no 409/04.

Considerando que a CVM é uma entidade autárquica em regime especial cujas normas não estão subordinadas hierarquicamente àquelas emanadas pelo legislador (em decorrência do processo denominado pela doutrina administrativista como "descentralização" ${ }^{57}$ ), podemos concluir que os métodos de hermenêutica jurídica também se aplicam aos atos normativos editados pela referida autarquia.

Isso implica dizer que a discussão travada no Processo Administrativo no 2010/3326 não tem o condão de substituir a intenção do regulador pelo significado que mais convém ao ente particular, mas sim interpretar o comando (que é genérico) de maneira teleológica, com o intuito de aproximá-lo da realidade do mercado (que podemos chamar de "costume") sem alterar a sua substância.

O cálculo individual em relação a cada aquisição de cotas é uma alternativa encontrada pelo mercado para contornar situações de imprecisão/omissão técnica, e, ao mesmo tempo, atender à regra geral de que esse pagamento deva ser feito como despesa do fundo.

Imagine-se a seguinte variação do valor da cota ao longo das semanas: D0 $=\mathrm{R} \$ 20,00 ; \mathrm{D} 1=\mathrm{R} \$ 30,00 ; \mathrm{D} 2=\mathrm{R} \$ 10,00 ; \mathrm{D} 3=\mathrm{R} \$ 25,00$. Ao calcular o "resultado do fundo" a partir da diferença no valor da cota entre "D3 - D0", teríamos uma performance de apenas $R \$ 5,00$, quando na verdade os cotistas que entraram na comunhão de recursos em D2 obtiveram valorização de $125 \%$. Dessa forma, o cálculo individual seria capaz de levar em consideração esse tipo de peculiaridades, comumente observadas no dia a dia da indústria.

"Na verdade, a descentralização de atividades da pessoa pública para suas entidades, especialmente para as autarquias, surge da necessidade de se atribuírem competências típicas da Administração Pública para outras pessoas jurídicas que possam, de forma autônoma e nos limites da legislação fundadora, administrar e executar os serviços públicos de maneira mais eficiente." (MENDES, Gilmar Ferreira et. al.. Curso de Direito Constitucional. 4ạ ed. rev. e atual. São Paulo: Saraiva, 2009, p. 878). 
Ressalte-se que a aparente solução de ajuste sobre a performance individual, prevista no §3으 do artigo 62, não é capaz de equacionar toda a gama de situações que podem se apresentar nos fundos de investimento.

Considere um fundo, por exemplo, cujo valor da cota aumentou linearmente durante o semestre de apuração. Nesse caso, é nítido que aqueles que aplicaram ao longo do período usufruíram de performance diferente (menor, no caso) do que aqueles que já eram cotistas no início do período.

Nessa hipótese, o ajuste individual não pode ser utilizado porque o valor da cota adquirida é superior ao valor da mesma na última data de cobrança, ferindo o disposto na ICVM no 409/04, ou seja, o método defendido pela CVM também impõe ônus não equitativos para os cotistas.

Observa-se, ainda, que a linha de argumentação utilizada pelo DiretorRelator OTAVIO YAZBEK no sentido de que o cálculo individual é "opaco" demonstra-se enfraquecida em virtude de própria jurisprudência administrativa da CVM.

De fato, um cotista não pode ter acesso às movimentações financeiras dos demais condôminos, já que estes dados são protegidos por sigilo. O mesmo não ocorre, porém, quando o solicitante é a CVM - no regular exercício de suas competências, naturalmente.

A Lei Complementar n 105/2001 dispõe, no §3으 do artigo 2ำ, que a CVM pode, ao exercer a sua função de fiscalização, ter acesso aos dados referentes aos serviços prestados por instituições financeiras ou equiparadas:

"Art. 2o O dever de sigilo é extensivo ao Banco Central do Brasil, em relação às operações que realizar e às informações que obtiver no exercício de suas atribuições.

$\S 10$ O sigilo, inclusive quanto a contas de depósitos, aplicações e investimentos mantidos em instituições financeiras, não pode ser oposto ao Banco Central do Brasil:

1 - no desempenho de suas funções de fiscalização, compreendendo a apuração, a qualquer tempo, de ilícitos praticados por controladores, administradores, membros de conselhos estatutários, gerentes, mandatários e prepostos de instituições financeiras;

II - ao proceder a inquérito em instituição financeira submetida a regime especial.

(...) 
§3 0 disposto neste artigo aplica-se à Comissão de Valores Mobiliários, quando se tratar de fiscalização de operações e serviços no mercado de valores mobiliários, inclusive nas instituições financeiras que sejam companhias abertas." (grifo nosso)

Conforme decisão proferida na análise do Processo Administrativo no 2003/13246, o Diretor-Relator MARCELO TRINDADE firmou o entendimento no qual os registros de movimentação de cotas devem ser arquivados enquanto existir o fundo:

"Ficou provado nos autos, pela inspeção realizada pela CVM, que os administradores não têm prova de que houve o resgate das cotas do investidor reclamante. Essa prova cumpria a eles guardar não apenas pelo prazo de 5 (cinco) anos, mas sim por prazo indeterminado, porque ela se faz através dos lançamentos no registro de movimentação de cotas. Esse registro é que se mantém enquanto existe o fundo. Não era preciso guardar os recibos, a comprovação do pagamento, apenas exibir o registro da movimentação de cotas do fundo. $E$ isso os administradores sucessivos não lograram fazer.." ${ }^{15}$ (grifo nosso)

A partir do momento em que os administradores estão obrigados a arquivar os principais elementos concernentes às aplicações/resgates nos fundos de investimento, conclui-se que a CVM pode, desde que observados os princípios que regem os procedimentos administrativos, analisar as referidas informações.

Desse modo, confrontando os resultados obtidos na fiscalização com os dados da variação do valor da cota de cada fundo publicados diariamente ${ }^{59}$ no site da própria autarquia, a CVM é potencialmente capaz de checar (registre-se: a posteriori) se o cálculo da taxa de performance foi realizado da maneira adequada.

O que fica claro da análise da decisão da CVM é a preocupação da autarquia em assegurar a proteção incondicional do investidor de varejo, expressando um dos seus papéis institucionais previstos na Lei no 6.385/76 ${ }^{60}$ :

CVM, Processo Administrativo CVM no RJ 2003/13246, Diretor-Relator Marcelo Trindade, 05 dez. 2006. ICVM no 409/04: "Art. 68. O administrador do fundo está obrigado a: I - divulgar, diariamente, o valor da cota e do patrimônio líquido do fundo aberto." 
“Art . 8o Compete à Comissão de Valores Mobiliários:

I - regulamentar, com observância da política definida pelo Conselho Monetário Nacional, as matérias expressamente previstas nesta Lei e na lei de sociedades por ações;

II - administrar os registros instituídos por esta Lei;

III - fiscalizar permanentemente as atividades e os serviços do mercado de valores mobiliários, de que trata o Art. 10, bem como a veiculação de informações relativas ao mercado, às pessoas que dele participem, e aos valores nele negociados;

IV - propor ao Conselho Monetário Nacional a eventual fixação de limites máximos de preço, comissões, emolumentos e quaisquer outras vantagens cobradas pelos intermediários do mercado;

V - fiscalizar e inspecionar as companhias abertas dada prioridade às que não apresentem lucro em balanço ou às que deixem de pagar o dividendo mínimo obrigatório." (grifo nosso)

Ocorre que, ao se apressar em evitar que um cotista que não tenha obtido valorização das suas cotas rateie a despesa atinentes à taxa de performance com os demais condôminos (e partindo do princípio que, conforme explicado anteriormente, o método do cálculo individual não vai de encontro à ICVM nㅇ 409/04, mas tão somente supre uma lacuna deixada pelo caráter amplo do dispositivo), a CVM amplia o seu perímetro de atuação adentrando num campo obrigacional eminentemente privado.

De acordo com o artigo 30 da ICVM no 409/04, antes de aportar recursos nos fundos, o potencial investidor é orientado a ler atentamente o Regulamento e o Prospecto para se familiarizar com as características e riscos do fundo, para só então assinar o Termo de Adesão manifestando sua concordância com todas as informações disponibilizadas:

"Art. 30. Todo cotista ao ingressar no fundo deve atestar, mediante termo próprio, que:

I - recebeu o regulamento e, se for o caso, o prospecto;

II - tomou ciência dos riscos envolvidos e da política de investimento;

III - tomou ciência da possibilidade de ocorrência de patrimônio líquido negativo, se for o caso, e, neste caso, de sua responsabilidade por conseqüentes aportes adicionais de recursos."

Nesse sentido, o investidor, antes de ingressar na comunhão de recursos, toma ciência que a taxa de performance será calculada individualmente em 
relação a cada aquisição de cotas, não obstante ser cobrada diretamente do fundo na forma de Encargo.

Não restam dúvidas, porém, que, do ponto de vista obrigacional, esse investidor voluntariamente (ou seja, de maneira autodeterminada) se submete a uma norma que potencialmente impõe o supracitado ônus à parcela do seu patrimônio, posto que a decisão de alocar dinheiro em fundos é de cunho estritamente pessoal.

Desviando o foco para o direito contratual, podemos considerar a assinatura do termo de adesão como a celebração de um ato formal entre duas partes (investidor "versus" condomínio, representado pelo Administrador). Dessa forma, é preciso assegurar o campo de incidência do princípio da autonomia da vontade, corolário da liberdade que impera, sobretudo, no mercado financeiro.

Nos ensinamentos de CARLOS ROBERTO GONÇALVES:

“(...) as pessoas são livres para contratar. Essa liberdade abrange o direito de contratar se quiserem, com quem quiserem e sobre o que quiserem, ou seja, o direito de contratar e de não contratar, de escolher a pessoa com quem fazê-lo e de estabelecer o conteúdo do contrato.

O princípio da autonomia da vontade se alicerça exatamente na ampla liberdade contratual, no poder dos contratantes de disciplinar os seus interesses mediante acordo de vontades, suscitando efeitos tutelados pela ordem jurídica." ${ }^{61}$

A liberdade para contratar, que é garantida pelo artigo 421 do Código Civil ("a liberdade de contratar será exercida em razão e nos limites da função social do contrato"), entretanto, não é absoluta/inquestionável, e encontra limites principalmente nos imperativos de caráter público.

Ocorre que no caso em questão não há interesse social que esteja sendo ameaçado/ferido pela convenção particular. Ou seja, o princípio da supremacia da ordem pública não pode ser invocado em casos como o abordado anteriormente para justificar a decisão tomada pela CVM, pois os efeitos 
decorrentes do cálculo da taxa de performance passam ao largo de interferir negativamente na ordem pública ou bons costumes.

Corroborando o raciocínio acima, é válido destacar o teor do artigo 1.317 do Código Civil, que disciplina os direitos e deveres dos condôminos, e se aplica a questão considerando a natureza jurídica condominial dos fundos de investimento:

“Art. 1.317 Quando a dívida houver sido contraída por todos os condôminos, sem se discriminar a parte de cada um na obrigação, nem se estipular solidariedade, entende-se que cada qual se obrigou proporcionalmente ao seu quinhão na coisa comum." (grifo nosso)

Primeiramente, entenda-se por "dívida", no caso, a obrigação de pagar a taxa de performance ao gestor.

Em seguida, sabe-se que ela foi "contraída por todos os condôminos, sem se discriminar a parte de cada um na obrigação", tendo em vista que é uma despesa do fundo que deve ser debitada diretamente do patrimônio líquido, conforme disposto no Regulamento e na própria ICVM no 409/04.

Por fim, o legislador, afirma que cada condômino "se obrigou proporcionalmente ao seu quinhão na coisa comum", restando claro o respaldo do cálculo individual da taxa de performance em lei federal, o que afasta por completo qualquer justificativa de invocação implícita da supremacia da ordem pública por parte da CVM.

\section{- 2.2.3. Análise sob a ótica do CDC}

Poder-se-ia cogitar a hipótese de alteração do posicionamento defendido acima caso o cenário fosse visualizado com a utilização de viés consumerista, já que o CDC (a Lei no 8.078/1990 - Código de Defesa do Consumidor) estabelece normas de proteção notadamente mais profundas que aquelas dispostas no Código Civil. 
Aqueles que defendem a aplicação do CDC (corrente majoritária, especialmente na jurisprudência brasileira) invocam, em sua maioria, argumentos semelhantes - que serão analisados a seguir.

Primeiramente, é feita referência à legislação, através da ampla definição de "serviço" contida no artigo 3으, § 2ㅇ, do CDC, que dispõe:

\begin{abstract}
"Art. $3^{\circ}$ Fornecedor é toda pessoa física ou jurídica, pública ou privada, nacional ou estrangeira, bem como os entes despersonalizados, que desenvolvem atividade de produção, montagem, criação, construção, transformação, importação, exportação, distribuição ou comercialização de produtos ou prestação de serviços.

(...)

$\S 2^{\circ}$ Serviço é qualquer atividade fornecida no mercado de consumo, mediante remuneração, inclusive as de natureza bancária, financeira, de crédito e securitária, salvo as decorrentes das relações de caráter trabalhista." (grifo nosso)
\end{abstract}

A constitucionalidade do dispositivo destacado foi questionada na Ação Direta de Inconstitucionalidade (ADI) no $2.591^{62}$, proposta pela Confederação Nacional do Sistema Financeiro (CONSIF). O Supremo Tribunal Federal, no entanto, manifestou-se pela constitucionalidade do trecho supracitado, frustrando as expectativas as instituições financeiras que confiavam na alteração da redação do artigo 3ำ, § 2ำ, do CDC.

O fato curioso dessa decisão, e que merece destaque, foi o voto do então Ministro NELSON JOBIM, que identifica quais serviços bancários são aptos a caracterizar uma relação de consumo. Ao listar (em rol não exaustivo) as atividades dessa categoria (i) com cobrança de tarifa e (ii) que não envolvem empréstimos e créditos, o Ministro cita expressamente a "administração de fundos ou de patrimônio" ${ }^{63}$.

Nesse sentido, ainda que o caso específico dos fundos de investimento não tenha sido atacado pelo mérito da ação, não se discute que o voto do matéria, uma vez que o artigo 192 da Constituição Federal de 1988 preceitua que o sistema financeiro nacional deve ser regulado através de leis complementares - espécie normativa diversa daquela ostentada pelo CDC, qual seja, de lei ordinária. 
Ministro NELSON JOBIM é um importante indicativo de como o STF enxerga a problemática.

Some-se a isso a edição da Súmula no 297 do Superior Tribunal de Justiça (STJ), que foi editada em 2004 (ou seja, anteriormente ao julgamento da ADI no 2.591), e contribui para a conclusão de que os tribunais superiores compartilham do mesmo entendimento nesse aspecto.

"O Código de Defesa do Consumidor é aplicável às instituições financeiras."

Neste momento, vale uma breve reflexão. A ICVM no 409 não estabelece que as atividades do administrador de um fundo de investimento devam ser necessariamente desempenhadas por uma instituição financeira. 0 parágrafo único do artigo 3o da Instrução nos remete apenas à prévia autorização da autarquia:

Para regulamentar a questão, a CVM editou a ICVM no 306/99, que dispõe sobre a administração de carteira de valores mobiliários e, mais uma vez, não restringe essa atividade às instituições financeiras.

Diante do exposto, pode surgir a seguinte dúvida: considerando que tanto os gestores quanto os administradores não precisam se organizar na forma de instituição financeira, o entendimento do STF e do STJ seria aplicável apenas à parte da indústria de fundos de investimento?

Teoricamente, sim. Mas na prática, não. A explicação encontra-se no artigo 57, §6ㅇ da ICVM nํ 409:

\footnotetext{
"§60 Os fundos administrados por instituições financeiras não precisam contratar os serviços previstos nos incisos III e V, do art. 56 quando os mesmos forem executados pelos seus administradores, que nestes casos serão considerados autorizadas para a sua prestação."
} 
O aumento dos custos gerado pela utilização de um administrador que não seja instituição financeira leva a uma ineficiência que não interessa aos cotistas, pois haveria a necessidade de contratação de prestadores de serviço para o desempenho das atividades de (i) tesouraria, controle e processamento dos títulos e valores mobiliários, e (ii) escrituração da emissão e resgate de cotas.

É por esse motivo que a indústria de fundos em sua esmagadora maioria revela administradores que são instituições financeiras ou entidades equiparadas (ex: sociedades distribuidoras de títulos e valores mobiliários, bancos de investimento, sociedade corretora, etc.).

O que aconteceria, porém, se a conduta lesiva ao cotista derivasse de atuação do gestor do fundo, que, neste exemplo, não é uma instituição financeira? Estaria o cotista descoberto da tutela consumerista caso o dano fosse discutido perante o Poder Judiciário?

Os defensores da aplicabilidade do CDC à questão invocariam o §2으 do artigo 57 da ICVM no 409/04, que impõe como requisito para a contratação de prestadores de determinados serviços (dentre eles o de gestão da carteira) a cláusula de solidariedade entre o terceiro e o administrador ${ }^{64}$ por eventuais prejuízos causados aos cotistas em virtude das condutas contrárias à lei, ao regulamento e aos atos normativos expedidos pela CVM.

Embora nosso posicionamento seja o da não aplicabilidade desse diploma à relação "cotista x fundo de investimento" (como será exposto mais adiante), ainda assim a situação referente à taxa de performance permaneceria inalterada, pois todos os direitos básicos garantidos no Capítulo III do CDC - que guardam alguma relação com o caso concreto - foram respeitados.

Não há que se falar em divulgação de informação incompleta e/ou obscura (inciso III do artigo 60 c/c artigo 31), uma vez que o Regulamento do Fundo é claro ao explicitar os métodos utilizados pela administradora para calcular e debitar os valores atinentes à taxa de performance. 
Além disso, a assinatura do cotista no termo de adesão contribui para a presunção de conhecimento prévio das características do produto, estando o procedimento de ingresso no Fundo de acordo com o disposto no artigo 46 do referido diploma legal:

\footnotetext{
"Art. 46 Os contratos que regulam as relações de consumo não obrigarão os consumidores, se não lhes for dada a oportunidade de tomar conhecimento prévio de seu conteúdo, ou se os respectivos instrumentos forem redigidos de modo a dificultar a compreensão de seu sentido e alcance." (grifo nosso)
}

Pelos mesmos motivos a eventual alegação de publicidade enganosa ou abusiva (artigo 6으, inciso IV) não se aplica à taxa de performance.

Tampouco adequa-se à questão o conceito trazido pelo inciso $\mathrm{V}$ do artigo 60 do referido diploma legal, que garante ao consumidor a modificação das cláusulas contratuais que estabeleçam prestações desproporcionais ou sua revisão em razão de fatos supervenientes que as tornem excessivamente onerosas.

O assunto não versa, entretanto, sobre prestações desproporcionais ou excessivas por fatos supervenientes, já que as despesas pagas a título de taxa de performance (ii) que hoje são suportadas por cotistas que não obtiveram rentabilidade nas suas aplicações individuais amanhã podem beneficiá-lo, ou seja, trata-se de situação típica do mercado financeiro que proporciona eventos imprevisíveis por natureza, e (i) são cobradas sempre na forma e através de percentual pré-estabelecidos no Regulamento, que só podem ser alterados mediante aprovação da Assembleia Geral de Cotistas do Fundo.

Além disso, para que um cotista sofra desvalorização em suas cotas de maneira "desproporcional"/"excessiva" em virtude de rendimentos auferidos por outros investidores que aportaram recursos em momentos que depois viriam a se revelar melhores é preciso a conjugação de inúmeros fatores altamente improváveis (ex: queda abrupta no valor das cotas + aporte de recursos de novos investidores no fundo numa situação com viés de baixa aparentemente desfavorável + valorização acentuada do patrimônio do fundo até o patamar préqueda). 
Não há, dessa forma, a incidência de nenhuma abusividade na cláusula que aborda o cálculo individual da taxa de performance, ainda que, num primeiro momento, a formalização da relação entre cotista e Fundo (representado pelo seu Administrador) revista-se de contornos característicos de um contrato de adesão ${ }^{65}$ (artigo 54 do CDC).

\section{- 2.2.4. Não aplicabilidade do CDC aos cotistas}

Conforme demonstrado no item acima, entendemos que a configuração do cotista de fundo de investimento como "consumidor" não demandaria alterações substanciais na maneira pela qual a taxa de performance é tratada pelo Regulamento dos fundos que calculam a taxa de performance individualmente.

As maiores implicações seriam visualizadas, no entanto, no desenrolar de uma eventual lide judicial. Se um cotista que questionasse em juízo os critérios através dos quais o administrador do Fundo apurou a taxa de performance fosse encarado como "consumidor", fatalmente haveria o reconhecimento da (i) responsabilidade objetiva pela reparação de eventuais danos (isto é, o administrador responderia independentemente da existência de culpa) e (ii) inversão do ônus da prova, caso suas alegações se revelassem verossímeis.

Em virtude das relevantes consequências que o parágrafo anterior elenca, é válido destacar um item específico para esclarecer todos os conceitos que circundam essa questão.

Primeiramente, é preciso encarar a questão sob o prisma econômico, pois a partir desta ótica os conceitos de "investir" e "consumir" são inteiramente opostos.

Ressalte-se, neste caso, que a atividade desempenhada por administradores/gestores de fundos de investimento jamais pode ser enquadrada no rol de serviços essenciais para a população (como ocorre, por exemplo, na relação do cidadão com fornecedores de água ou energia elétrica). Há, portanto, perfeita possibilidade do investidor rejeitar, pelos mais diversos motivos, as cláusulas propostas e buscar outro fundo disponível no mercado, sem que isso lhe cause danos irreversíveis ou o coloque em situação desconfortável. 
O investimento nada mais é do que a destinação dada ao excedente do patrimônio de um indivíduo que não foi utilizado para a satisfação das suas necessidades. $O$ ato de investir é precedido pela decisão de poupar, que, por sua vez, é a postergação do consumo para um momento futuro.

Nas palavras de MAILSON DA NÓBREGA ${ }^{66}$ e GUSTAVO LOYOLA:

"Fica claro que, economicamente, poupança e consumo são atos diametralmente opostos e mutuamente excludentes. Um implica o uso e o desgaste total ou parcial de um produto ou o uso de um serviço. O outro implica acumulação. $O$ consumo é a negação da poupança e vice-versa. Assim, a decisão de consumir implica automaticamente a decisão de não poupar." ${ }^{67}$

Noção semelhante das características do ato de consumir (e que não se adequam à decisão de investir em fundos) está presente nas lições de SERGIO CAVALIERI FILHO, qual seja, a "aquisição de um produto ou a utilização de um serviço para suprimento das suas próprias necessidades, de sua família, ou dos que se subordinam por vinculação doméstica ou protetiva a ele, e não para desenvolvimento de outra atividade negocial, significa dizer, ausência de intermediação, de reaproveitamento ou de revenda" ${ }^{68}$.

Fazendo um paralelo com o direito civil, nota-se que a interpretação dos autores citados anteriormente acerca dos fundamentos do "consumo" encontra fundamento na definição de "bem consumível" dada pelo Código Civil:

“Art. 86. São consumíveis os bens móveis cujo uso importa destruição imediata da própria substância, sendo também considerados tais os destinados à alienação."

Aproveitando a referência feita à legislação, passemos à análise dos fatos utilizando como base dois conceitos-chave apontados pelo próprio CDC:

Foi Ministro da Fazenda entre janeiro de 1988 e março de 1989.

NÓBREGA, Mailson da; LOYOLA, Gustavo. A caderneta de poupança e o Código do Consumidor. Revista de Direito Bancário e do Mercado de Capitais, volume 6, p. 256. CAVALIERI FILHO, Sergio. Programa de direito do consumidor. São Paulo: Atlas 2008, p. 56. 
"Art. $2^{\circ}$ Consumidor é toda pessoa física ou jurídica que adquire ou utiliza produto ou serviço como destinatário final.

(...)

Art. $3^{\circ}(\ldots)$

$\S 2^{\circ}$ Serviço é qualquer atividade fornecida no mercado de consumo, mediante remuneração, inclusive as de natureza bancária, financeira, de crédito e securitária, salvo as decorrentes das relações de caráter trabalhista." (grifo nosso)

Com relação ao primeiro deles (que revela a opção do legislador pela corrente subjetiva ${ }^{69}$ ), não é difícil verificar que, na relação entre "cotista $x$ administrador do fundo", nenhuma das pontas pode ser considerada o destinatário final.

O administrador (ou o gestor, caso o fundo tenha contratado com terceiros para prestação desse tipo de serviço) recebe os recursos do investidor e o integra no patrimônio líquido do fundo. A partir daí, passa a realizar a tarefa de alocação nos mais variados instrumentos e títulos e valores mobiliários, contribuindo para a eficiência do mercado entre entes deficitários e superavitários. Fica nítida, portanto, a função de intermediação dos recursos.

Conforme explicado por NELSON EIZIRIK:

"Assim, as instituições financeiras atuam no processo de intermediação financeira, transferindo fundos das pessoas que os têm em excesso (agentes superavitários) para aqueles que deles necessitam (agentes deficitários).

É pois evidente que entre a instituição administradora do fundo e aqueles que nele investem não se configura uma relação de consumo, uma vez que a instituição financeira repassa tais valores aos emissores dos títulos que compõem a sua carteira, restando clara a sua atividade de intermediação de recursos." ${ }^{\prime 70}$

Em contraposição à corrente maximalista ou objetiva, que nas palavras de SERGIO CAVALIERI FILHO, entende que a expressão destinatário final "deve ser interpretada de forma ampla, bastando à configuração do consumidor que a pessoa, física ou jurídica, se apresente como destinatário fático do bem ou serviço, isto é, que o retire do mercado, encerrando objetivamente a cadeia produtiva em que inseridos o fornecimento do bem ou a prestação do serviço" (CAVALIERI FILHO, Sergio. Programa de direito do consumidor. p. 50). carteira. Parecer solicitado pela ANBID e FEBRABAN. 28 out. 2002. 
O cotista, por sua vez, ao realizar o resgate das suas cotas, tampouco pode ser considerado como destinatário final, já que utilizará o capital disponibilizado para só então consumir, ou direcioná-lo para novos investimentos, etc. Fato é que ele não será o ponto final daquela cadeia.

Justamente por não ostentar a qualidade de destinatário final é que determinados cotistas não podem ser considerados "consumidores", como é o caso das Entidades Abertas/Fechadas de Previdência Complementar (cujos investimentos são regidos, respectivamente, pelas Resoluções CMN no 3.922/10 e 3792/09), por exemplo.

No que diz respeito ao "mercado de consumo", muitos doutrinadores defendem a tese de que nem todas as atividades desempenhadas pelas instituições financeiras podem ser abarcadas pela expressão "inclusive as de natureza bancária" do § 2 ㅇ do artigo 3ํ do CDC.

O marco divisório desses dois grupos seria a identificação das tarefas relacionadas à intermediação de recursos. Novamente invocando os ensinamentos do advogado NELSON EIZIRIK:

“Com efeito, os bancos, no atual cenário das relações econômicas, prestam uma gama de serviços que não se confundem com as atividades de instituições financeiras, quais sejam, aquelas relacionadas, direta ou indiretamente, à intermediação de crédito.

Tais serviços, oferecidos pelos bancos aos clientes, como destinatários finais, no mercado de consumo, dizem respeito, por exemplo, ao pagamento de contas, cobrança de títulos (contas, duplicatas, etc.), serviços de 'banco 24 horas', aluguel de cofres para a guarda de valores, e tantos outros que, até por sua natureza, poderiam ser prestados por instituições não bancárias." ${ }^{71}$

Outro ponto que merece ser estudado é o requisito da vulnerabilidade, inerente à figura de todos os consumidores, como preceitua o inciso I do Artigo 4ㅇ do CDC.

Explica SERGIO CAVALIERI FILHO que o consumidor "é reconhecido como a parte mais fraca da relação de consumo, afetado em sua liberdade pela 
ignorância, pela dispersão, pela desvantagem técnica ou econômica, pela pressão das necessidades, ou pela influência da propaganda". Tal característica é o princípio que norteia a existência do CDC, mas, por óbvio, não é comum a todos os cotistas de fundos de investimento.

O mesmo ocorre com relação à hipossuficiência, que, nas palavras do jurista, "é marca pessoal, limitada a alguns (...) mas nunca a todos os consumidores", complementando mais a frente ao dizer que a ela "legitima alguns tratamentos diferenciados (...) como, por exemplo, a previsão de inversão do ônus da prova"72.

Sem maiores esforços, podemos destacar que se excluem dessas categorias aqueles investidores qualificados elencados pelo artigo 109 da ICVM no 409/04, que notadamente não se encontram numa posição de fragilidade perante os prestadores de serviço do fundo:

"Art. 108. Pode ser constituído fundo de investimento destinado, exclusivamente, a investidores qualificados.

Art. 109. Para efeito do disposto no artigo anterior, são considerados investidores qualificados:

I- instituições financeiras;

II - companhias seguradoras e sociedades de capitalização;

III - entidades abertas e fechadas de previdência complementar;

IV - pessoas físicas ou jurídicas que possuam investimentos financeiros em valor superior a $\mathrm{R} \$ 300.000,00$ (trezentos mil reais) e que, adicionalmente, atestem por escrito sua condição de investidor qualificado mediante termo próprio, de acordo com o Anexo l;

$\mathrm{V}$ - fundos de investimento destinados exclusivamente a investidores qualificados;

VI - administradores de carteira e consultores de valores mobiliários autorizados pela CVM, em relação a seus recursos próprios;

VII - regimes próprios de previdência social instituídos pela União, pelos Estados, pelo Distrito Federal ou por Municípios." (grifo nosso)

Leio ARNOLD WALD:

“(...) é possível concluir que a qualificação do investidor qualificado se dá em razão de suas características, considerando que têm eles melhores condiç̃̃es que o investidor comum de avaliar os riscos das operações das quais participa ou pretende participar, sem necessitar de maior protecão regulatória. Em 
geral, o investidor comum é considerado carente de maior proteção a ser dada pelo Estado, por meio de regras mais rígidas dirigidas às companhias emissoras de valores mobiliários e aos intermediários. ${ }^{173}$ (grifo nosso)

Cotistas que atestam por escrito (mediante assinatura de Termo específico, cuja minuta encontra-se no Anexo 1 da própria ICVM no 409/04) deter conhecimento sobre o mercado financeiro e de capitais suficiente para que não Ihe sejam aplicáveis um conjunto de proteções legais e regulamentares não podem ser considerados consumidores. Faltam-lhes, simultaneamente, a condição de vulnerabilidade e hipossuficiência, já que possuem "larga formação e experiência no mercado de capitais" ${ }^{74}$.

Para finalizar a questão, lembramos que existe a possibilidade do cotista ser remunerado pela valorização dos recursos aplicados nos fundos, o que, por natureza, não se coaduna com a ação de consumir. Considerando todo o exposto neste item, concluímos que a melhor interpretação para a condição do cotista de fundo de investimento é a sua caracterização como investidor do mercado financeiro, e não consumidor.

\section{- 2.2.5. Soluções encontradas no mercado internacional}

Os fundos de investimento se revestem de diferentes roupagens jurídicas e estão submetidos aos mais variados sistemas regulatórios ao redor do mundo, refletindo as peculiaridades econômicas e históricas de cada mercado.

Nos Estados Unidos (EUA), por exemplo, os mais comuns são os Hedge Funds e os Mutual Funds. Em breve resumo, enquanto o primeiro é destinado a investidores com patrimônio elevado (divididos pela legislação em mais de uma categoria, como, por exemplo, Qualified Eligible Person, Accredited Investor, Qualified Purchaser ou Sophisticated clients), o segundo geralmente é ofertado a 
investidores de varejo (e, consequentemente, sujeita-se a uma séria de restrições adicionais, tais como controle do nível de alavancagem e liquidez).

A organização federativa dos EUA permite que determinados Estados, com o intuito de fomentar a economia local, editem leis mais atrativas tanto do ponto de vista obrigacional quanto fiscal, o que acaba por atrair, inclusive, investidores internacionais.

Para analisar a questão da taxa de performance, utilizaremos como base o regramento jurídico do Estado de Delaware, talvez o maior destino de gestores de recursos norte-americanos.

Em Delaware, temos duas principais formas de organização dos fundos: Limited Liability Company ("LLC", reguladas pelo Delaware Limited Liability Company Act - "Act") e Limited Partnership ("LP", de acordo com o Delaware Revised Uniform Limited Partership Act - “DRULPA").

Ambas são baseadas numa política de respeito à liberdade de contratar, para que sejam criadas regras de governança que reflitam precisamente os interesses daqueles que as estão constituindo. Nesse contexto, tanto o Act quanto a DRULPA procuram estabelecer um complexo de normas subsidiárias (conhecidas como background rules) com permissão expressa para serem alteradas caso seja esse o interesse dos particulares.

O objetivo do legislador norte-americano é garantir a existência de conceitos-base (default rules) que possam guiar o Judiciário caso a documentação dos fundos venha a ser omissa em relação a uma determinada questão.

A diferença entre LC e LLP reside no fato da segunda obrigatoriamente ter que indicar um general partner responsável pela gestão do fundo com responsabilidade ilimitada, ao contrário dos demais participantes (limited partners), que tem responsabilidade limitada (ou seja, não respondem com o patrimônio pessoal pelas dívidas e obrigações contraídas pelo fundo que excedam o capital aportado).

No entanto, a compatibilidade entre as estruturas é tamanha que o mercado - sempre buscando soluções criativas - passou a estruturar o general partner na forma de uma LLC, garantindo a responsabilidade limitada não só do 
general partner como também dos seus respectivos beneficiários finais (ultimate owners).

A liberdade e a estrutura societária das LLCs e LPs facilita a resolução de arestas envolvendo a taxa de performance (performance fee ou incentive fee), mediante a conjugação do sistema de (i) capital account (que cria uma espécie de conta específica para cada investidor) e (ii) classes e séries de cotas.

$\mathrm{Na}$ data escolhida para o pagamento da taxa de performance, o montante devido ao gestor será descontado proporcionalmente de cada capital account (desde que, logicamente, aquela classe tenha registrado valorização superior ao benchmark) e destinado à aquisição de novas cotas do fundo pelo próprio gestor, mediante depósito dos recursos para a sua respectiva capital account.

Alternativamente a esse método, é possível que se estabeleça o pagamento das riquezas diretamente o gestor, sem a necessidade de criação de uma capital account como intermediária. Além de poder gerar ineficiências fiscais para alguns tipos de investidores norte-americanos, existe um forte apelo comercial para que o gestor de recursos tenha dinheiro próprio aplicado no fundo, já que isso demonstra confiança no sucesso do veículo.

Paralelamente às capital accounts, é utilizada a técnica das classes e séries de cotas, que são definidas por THOMAS P. LEMKE da seguinte maneira:

"In essence, the hedge fund establishes a new series of shares (or other interests) on its books on each date investments are made. All investors who invest in the hedge fund on any particular date are treated the same and any performance fee relating to their investments is calculated with reference to the performance of their particular series." ${ }^{75}$

Através do sistema acima, não restam dúvidas que a taxa de performance será devida apenas por aqueles que, de fato, obtiveram rendimentos no período, já que foram criados métodos (classes e séries de cotas + capital account) que viabilizam o controle individual dos recursos de cada investidor. 
Os autores norte-americanos, porém, também estudam fundos de investimento organizados sob a forma de corporations. Apesar de não serem muito comuns em solo americano (pois lá as corporations estão sujeitas a dois níveis de tributação: uma no nível dos investimentos do fundo, e outra no nível dos cotistas), essa é uma estrutura bastante presente em diversas jurisdições.

Por se assemelhar aos fundos brasileiros regidos pela ICVM nำ09/04 embora ainda guardem importantes diferenças ${ }^{76}$-, partiremos desse ponto para analisar os caminhos pelos quais o regulador brasileiro pode se guiar para, no futuro, acabar de vez com os debates sobre a taxa de performance.

Os impasses enfrentados pelas corporations são muito parecidos com aqueles vivenciados pelos fundos brasileiros e que foram alvo do Processo Administrativo no 2010/3326.

DOUGLAS L. HAMMER resume de maneira clara e direta os problemas oriundos da obrigatoriedade de termos apenas um valor de cota para cada classe criada nas corporations que admitem aplicações e resgates ao longo do ano (observa-se que a realidade dos fundos da ICVM no 409/04 encaixa-se quase que perfeitamente à situação, exceto no que diz respeito à questão da classe de cotas):

"The corporate structure requires a single net asset value for each class and series of shares, unlike a partnership or limited liability company with a separate capital account for each investor. A performance fee charged to a corporation is an expense that affects the net asset value of each share in the same way. Without some adjustment, an investor that purchases shares in an offshore hedge fund on a date other than the first day of the period over which the performance fee is calculated would suffer the same per-share decrease in net asset value on payment of the performance fee at the end of the period as investors that held shares from the beginning of the period, even if the new investor's shares enjoyed less appreciation."

E mais a frente complementa:

As corporations, ao contrário dos fundos da ICVM no 409/04, admitem a criação de classes de cotas, mas se aproximam do caso brasileiro ao exigir um valor único para cada classe. Ou seja, não existe a figura da capital account. Outra importante diferença diz respeito à tributação, pois os fundos brasileiros são isentos do recolhimento de impostos nas suas operações, de modo a evitar a bitributação dos cotistas no momento do resgate. 
"Similarly, an investor that purchases shares on other than the first day of the performance fee calculation period at a time when the net asset value of the shares is less than its value at the beginning of the period will not be charged a performance fee at the end of the period if the net asset value has then increased back to its value at the beginning of the period, even though that investor's shares will have appreciated. Thus, equitable problems arise in charging performance fee to an offshore hedge fund, because investors may invest at different times during the year, when the offshore hedge fund has accrued differing performance fees or high-water marks." ${ }^{\text {77 }}$

Diante desse cenário, os agentes de mercado se viram com o desafio de criar soluções para resolver a ineficiência da aferição/cobrança da taxa de performance em fundos abertos à captação/resgate, e as principais saídas encontradas serão expostas a seguir:

\section{1) Equalização (Equalization methodologies)}

Surgiu com o objetivo de garantir que cotistas e gestores recebam um tratamento justo, mediante cálculo preciso dos incentivos devidos a título de performance, que altera o valor de face de cada cota para atingir o cenário ideal. Segundo DOUGLAS L. HAMMER:

"The 'equalization of shares' method equalizes the investment of an investor admitted at a time when the other shareholders are already subject to an accrued performance fee (because the hedge fund has appreciated) or when the other shareholders have an unrecouped loss and are below their high-water mark (because the hedge fund has depreciated). ${ }^{78}$

Por exemplo: em um dado fundo de investimento, o valor da cota é $\mathrm{R} \$ 100,00$ no início do exercício social, e o benchmark da taxa de performance é $20 \%$ da rentabilidade contabilizada. Um investidor $X$ compra cotas desse fundo no meio do período, quando elas já estão valendo $R \$ 120,00$. O correto seria que ele não arcasse com os custos da taxa de performance devida pelos demais 
cotistas que obtiveram valorização de $\mathrm{R} \$ \mathbf{2 0 , 0 0}$ até aquele determinado momento. Dessa forma, os registros do fundo creditarão ao investidor $X$ um equalization deposit no valor de $\mathrm{R} \$ 4,00$ (isto é, $20 \%$ de $\mathrm{R} \$ 20,00$ ), que passa a integrar o patrimônio do fundo. Após o pagamento da taxa de performance por todos os cotistas na data pré-estabelecida no Regulamento, o equalization deposit, se positivo, é convertido em novas cotas para o investidor X. Se negativo, estará assegurado que o investidor $\mathrm{X}$ não foi prejudicado.

Procedimento semelhante ocorreria se, no momento de ingresso no fundo, a cota adquirida pelo investidor $X(R \$ 80,00)$ ostentasse valor menor do que a dos demais cotistas $(R \$ 100,00)$ no início do exercício social. Nesse caso, ao invés de um equalization deposit haveria um depreciation deposit ou redemption for no consideration (- $\mathrm{R} \$ 4,00)$, ou seja, uma parte do patrimônio aportado no fundo pelo investidor $X$ seria mantida em conta segregada, para eventualmente ser destinada ao gestor na hipótese de valorização dessas cotas até o valor observado no início do exercício social (qual seja, $\mathrm{R} \$ 100,00$ ).

As maiores desvantagens desse método passam, naturalmente, por aspectos operacionais. $\mathrm{O}$ controle de todas as séries de cotas resultaria em altos custos com softwares, obrigatoriedade de contratação de funcionários especializados e aumento da margem de erro, fatores que ajudam a entender porque a Equalização é pouco vista atualmente no mercado.

Além disso, é preciso destacar que a comparabilidade entre fundos fica prejudicada, tanto para os cotistas quanto para o próprio gestor. Ou seja, a complexidade das informações geradas para fundos que utilizam essa técnica faz com que esses veículos sejam analisados de forma separada do resto da indústria ${ }^{79}$.

\section{2) Classes e séries de cotas (Multi-series method)}

Atitude que se revela na contramão da tendência dos atos da CVM. No Edital de Audiência Pública SDM no 06/11, que visa alterar a ICVM no 409/04, a CVM propõe a criação de dois documentos (Demonstração de Desempenho e Lâmina de Informações Essenciais) cujo objetivo maior é "estabelecer mecanismos que auxiliem o investidor a melhor comparar os diversos fundos de investimento oferecidos no mercado". 
Como explicado anteriormente, a criação de diferentes classes de cotas é uma solução relativamente simples que, juntamente regras adicionais, é capaz de colocar um ponto final nos impasses relativos à questão da taxa de performance. Como cada uma das séries tem um valor próprio (variando de acordo com a data de integralização dos recursos e o rendimento do fundo a partir desse determinado instante) elas serviriam de base para o cálculo mais preciso da taxa.

Para evitar a existência de um incontável número de séries, findo o exercício social todas as diferentes séries que apresentassem rentabilidade positiva seriam reunidas para o futuro nas chamadas master series, com o intuito de facilitar o trabalho do administrador.

\section{3) Pagamento mensal (Monthly accrual)}

Esse método, em resumo, sugere que a taxa de performance seja calculada e cobrada mensalmente. Não restam dúvidas que ele poderia ser utilizado apenas por um rol extremamente restrito de fundos de investimento no Brasil, haja vista que os objetivos seriam alcançados apenas em fundos que admitem aplicações e resgates mensais - o que, definitivamente, não corresponde à realidade brasileira.

O pagamento mensal eliminaria a necessidade de se estabelecer controles internos para compensar a valorização/depreciação das cotas. Entretanto, ele nada mais é do que uma tentativa de simplificação grosseira dos dois métodos detalhados anteriormente.

Por fim, é certo que fundos com essa característica apresentariam desvantagens competitivas com relação ao resto da indústria.

\section{4) Justiça "imperfeita" (Rough justice)}

Confira-se a proposta de DOUGLAS L. HAMMER que, no nosso entendimento, é a única que admite aplicação imediata no cenário brasileiro, e 
cujo raciocínio deveria ter sido levada em consideração pela CVM, inclusive na análise do Processo Administrativo no 2010/3326:

"As the name 'rough justice' suggests, some offshore hedge funds choose simply to accept these inequities on the theory that investors should perceive that, over the time, they are likely to receive both the benefits and the burdens of the structure." (grifo nosso)

Exemplificando:

“(...) assume that Investor A's shares originally bore their pro rata portion of the offshore hedge fund's performance fee even though they did not appreciate. If a subsequent Investor B also purchases shares when the offshore hedge fund has accrued a performance fee, Investor A benefits because Investor B's shares will absorb part of the performance fee that otherwise would be charged to Investor A. ${ }^{\prime 80}$

Todos os demais métodos (com exceção do "Pagamento mensal", cujas peculiaridades impedem-no de se tornar um padrão de mercado) esbarram nos principais conceitos atinentes à cota dados pela ICVM no 409/04:

"Art. 10. As cotas do fundo correspondem a fraç̃es ideais de seu patrimônio, e serão escriturais e nominativas.

$\S 1^{\circ}$ As cotas do fundo conferirão iguais direitos e obrigações aos cotistas. $\S 2$ ○ 0 valor da cota do dia é resultante da divisão do valor do patrimônio líquido pelo número de cotas do fundo, apurados, ambos, no encerramento do dia, assim entendido, para os efeitos desta Instrução, o horário de fechamento dos mercados em que o fundo atue."

Verifica-se, dessa forma, que alguns dos mercados offshore, que são consideravelmente maduros e apresentam tracking records mais extensos que 0 brasileiro, criaram alternativas para as ineficiências geradas pelo cálculo individual da taxa de performance.

A ideia contida na Justiça "imperfeita", sem dúvida, é um sólido parâmetro a ser utilizado para embasar o pleito daqueles que optam pelo cálculo 
individual da taxa de performance em solo brasileiro, como, por exemplo, no caso do Processo Administrativo no 2010/3326. 


\section{Conclusão}

Durante todo o trabalho, procuramos, na medida do possível, ambientar o leitor no vasto universo que circunda os fundos de investimentos, sem a leviana intenção de esgotá-lo. Isso foi feito com o objetivo de realçar a importância da discussão levantada acerca da taxa de performance, procurando esclarecer que não se trata apenas de um detalhe técnico. Muito pelo contrário.

O debate acerca da correta visão acerca dos aspectos inerentes à taxa de performance no caso concreto nos remete à discussões extremamente basilares para o desenvolvimento do mercado de capitais brasileiro, dentre as quais destacamos (i) a natureza jurídica dos fundos de investimento, e (ii) a maneira pela qual o Poder Judiciário deve encarar os cotistas em eventuais litígios.

O debate acerca do primeiro dos pontos destacados acima é essencial, pois a corrente à qual nos filiamos defende que é possível impor tratamento diferenciado aos cotistas dos fundos especificamente no momento da cobrança de taxa de performance, tendo em vista a natureza jurídica sui generis dos referidos veículos. O segundo, por sua vez, é igualmente relevante, já que envolve a questão da segurança jurídica - essencial para o desenvolvimento da economia.

O argumento de que a interpretação compartilhada pela esmagadora maioria dos players do mercado alinha-se com aquela defendida neste estudo (e, consequentemente, afasta-se da visão da CVM) jamais poderia ser encarado como único ou suficiente.

A experiência histórica nos ensina que os participantes do mundo das finanças, por vezes, agem de acordo com o que lhes é mais conveniente, sem atentar para os riscos inerentes às suas condutas e as reais motivações. Não é por outro motivo que Warren Buffett afirmou, em certa ocasião, que as cinco palavras mais perigosas do mercado financeiro são: "Everybody else is doing it".

No caso específico da taxa de performance (corporificado no Processo Administrativo no 2010/3326), entretanto, entendemos que a realidade da indústria de fundos deve, sim, ser levada em consideração pela CVM, não como 
afronta à regra da ICVM no 409/04, mas como aprimoramento de um conceito que, na nossa opinião, merece ser devidamente aprofundado pelo regulador.

O mercado financeiro vive da evolução e da contínua busca por soluções criativas e inteligentes, razão pela qual foi trazida à colação a experiência internacional. A maneira pela qual os autores estrangeiros encaram a taxa de performance pode ser útil ao cenário brasileiro, seja através da disseminação de métodos como o da equalização, da aceitação de que as regras brasileiras geram a chamada Justiça "imperfeita", ou mesmo através de uma ampla reforma estrutural para que passe a ser admitida a criação de classes/séries de cotas.

Caso o órgão regulador permaneça defendendo a interpretação literal do comando da ICVM no 409/04 que rege o assunto, grande parte dos administradores de fundos são colocados em potencial risco (haja vista que utilizam praticamente os mesmos sistemas operacionais para calcular/pagar a taxa de performance).

Num cenário mais apocalíptico, poder-se-ia cogitar que, ao tomar conhecimento da maneira pela qual os agentes de mercado põem em prática o cálculo da taxa de performance, a CVM opte por rever a possibilidade de cobrança desse encargo em fundos destinados a cotistas não qualificados, por exemplo, com o intuito de proteger o investidor de varejo.

Ainda que não exista qualquer indicação concreta de que essa conduta tenha sido sequer ventilada, sem dúvidas ela traria consequências desastrosas para a indústria de fundos, criando obstáculos quase que intransponíveis principalmente para o segmento de gestores independentes, que ficaria eivado da sua principal fonte de remuneração.

De todo modo, temos a confiança que a decisão tomada no Processo Administrativo no 2010/3326 foi apenas a primeira de muitas outras futuras manifestações da CVM sobre a matéria. A cristalização de um entendimento jurisprudencial passa, necessariamente, pelo repetido estudo de casos semelhantes, até que os principais conceitos (e, por que não, os impactos econômicos) estejam devidamente sedimentados e esclarecidos para aqueles encarregados de julgar e estabelecer diretrizes. 
Nesse sentido, fica o desafio para a doutrina brasileira, que pode - e deve - adotar postura mais ativa, aprofundando (quantitativa e qualitativamente) os debates, artigos, textos, seminários, etc., ou seja, os materiais técnicos sobre fundos de investimento e seus aspectos correlatos. A literatura pátria ainda engatinha quando comparada ao vasto arcabouço jurídico elaborado por outros países, nos quais a doutrina, efetivamente, assume seu papel como de fonte do Direito e contribui, de forma direta, para o desenvolvimento consolidado do mercado financeiro e de capitais. 


\section{Referências Bibliográficas}

CAVALIERI FILHO, Sergio. Programa de direito do consumidor. São Paulo: Atlas $2008,345 p$.

COMISSÃO DE VALORES MOBILIÁRIOS, Processo Administrativo CVM no RJ 2002/3792, Diretor-Relator Luiz Antonio de Sampaio Campos, 08 abr. 2003.

COMISSÃO DE VALORES MOBILIÁRIOS, Processo Administrativo CVM no RJ 2003/13246, Diretor-Relator Marcelo Trindade, 05 dez. 2006.

COMISSÃO DE VALORES MOBILIÁRIOS, Processo Administrativo CVM no RJ 2008/1974, Diretor-Relator Otavio Yazbek, 23 jun. 2009.

COMISSÃO DE VALORES MOBILIÁRIOS, Processo Administrativo CVM no RJ 2010/3326, Diretor-Relator Otavio Yazbek, 31 mai. 2011.

EIZIRIK, Nelson Laks. Fundo de Investimento. Não Aplicação do CDC aos quotistas. Fato do príncipe consistente na mudança das regras de contabilização dos títulos de sua carteira. Parecer solicitado pela ANBID e FEBRABAN. 28 out. 2002.

EIZIRIK, Nelson Laks et. al.. Mercado de Capitais - regime Jurídico. Rio de Janeiro: Renovar, 2008. 624 p.

FORTUNA, Eduardo. Mercado Financeiro: produtos e serviços. 18a ed. rev. e atual. Rio de Janeiro: Qualitymark, 2010. 986 p.

FREITAS, Ricardo de Santos. Natureza Jurídica dos Fundos de Investimento. São Paulo: Quartier Latin, 2005. 287 p.

GONÇALVES, Carlos Roberto. Direito civil brasileiro, volume III: contratos e atos unilaterais. 5ạ. ed. rev. e atual. São Paulo: Saraiva, 2008, 693 p. 
HAMMER, Douglas et. al.. U.S. Regulation of Hedge Funds. 2005 Edition. American Bar Association, 407 p.

LEMKE, Thomas et. al.. Hedge Funds and Other Private Funds: Regulation and Compliance. 2008/2009 Edition. Thomson/West. 906 p.

LOYOLA, Gustavo. O futuro da regulação financeira. In: Garcia, Marcio; GIAMBIAGI, Fabio (Org.). Risco e Regulação: por que o Brasil enfrentou bem a crise e como ela afetou a economia mundial. Rio de Janeiro: Elsevier, 2010. P. 61 -78 .

MENDES, Gilmar Ferreira et. al.. Curso de Direito Constitucional. 4a ed. rev. e atual. São Paulo: Saraiva, 2009, 1486 p.

MONTEIRO, Luciana; PAVINI, Angelo. BNY Mellon autoriza reabertura de fundos da GWI. Valor Econômico, São Paulo, Disponível em < http://www.valor.com.br/financas/991814/bny-mellon-autoriza-reabertura-defundos-da-gwi>. Acesso em 30 out. 2011.

NEVES, Andrea Nogueira. Considerações sobre a tributação dos fundos de investimento fechados. In: MOSQUERA, Roberto Quiroga (Org.). O direito Tributário e o mercado financeiro e de capitais. São Paulo: Dialética, 2009. p. 68 83.

NÓBREGA, Mailson da; LOYOLA, Gustavo. A caderneta de poupança e o Código do Consumidor. Revista de Direito Bancário e do Mercado de Capitais, volume 6, p. 256.

OLIVA, Milena Donato. Indenização devida "ao fundo de investimento": qual quotista vai ser contemplado, o atual ou o da data do dano? Revista dos Tribunais, volume 904, DRT/2011/1026, página 73, fev. 2011. 
PEREIRA, Caio Mário da Silva. Instituições de direito civil - Volume IV. 20ạ ed. Rio de Janeiro, Editora Forense, 2009. 395 p.

SUPREMO TRIBUNAL FEDERAL, Tribunal Pleno, ADI 2.591 / DF, j. 07.06.2006, Rel. Min. Carlos Velloso, Brasília.

TRINDADE, Marcelo Ferraz; SANTOS, Aline de Menezes. Regulação e AutoRegulação no Brasil e a Crise Internacional. Disponível em < http://www.bmfbovespa.com.br/juridico/download/Artigo_MarceloTrindade.pd f>. Acesso em 09 set. 2011.

VILLAS BÔAS, Bruno. Fundos cambiais voltam ao centro das atenções. O Globo, Rio de Janeiro, p. 25, 26 set. 2011.

WALD, Arnold. O investidor qualificado no mercado de capitais brasileiro. Revista de Direito Bancário e do Mercado de Capitais, volume 32, p. 15.

YAZBEK, Otavio. Regulação do Mercado Financeiro e de Capitais. Rio de Janeiro: Elsevier, 2007. 316 p. 